\title{
Cajander larch (Larix cajanderi) biomass distribution, fire regime and post-fire recovery in northeastern Siberia
}

\author{
L. T. Berner ${ }^{1}$, P. S. A. Beck ${ }^{1}$, M. M. Loranty ${ }^{1, *}$, H. D. Alexander ${ }^{2, * *}$, M. C. Mack ${ }^{2}$, and S. J. Goetz ${ }^{1}$ \\ ${ }^{1}$ The Woods Hole Research Center, 149 Woods Hole Road, Falmouth, MA 02540-1644, USA \\ ${ }^{2}$ University of Florida, Department of Biology, P.O. Box 118525, Gainesville, FL 32611, USA \\ * currently at: Colgate University, Department of Geography, 13 Oak Drive, Hamilton, NY 13346, USA \\ ** currently at: University of Texas - Brownsville, Department of Biological Sciences, 80 Fort Brown, Brownsville, \\ TX 78520, USA
}

Correspondence to: L. T. Berner (lberner@whrc.org)

Received: 23 May 2012 - Published in Biogeosciences Discuss.: 25 June 2012

Revised: 10 September 2012 - Accepted: 16 September 2012 - Published: 15 October 2012

\begin{abstract}
Climate change and land-use activities are increasing fire activity across much of the Siberian boreal forest, yet the climate feedbacks from forest disturbances remain difficult to quantify due to limited information on forest biomass distribution, disturbance regimes and post-disturbance ecosystem recovery. Our primary objective here was to analyse post-fire accumulation of Cajander larch (Larix cajanderi Mayr.) aboveground biomass for a $100000 \mathrm{~km}^{2}$ area of open forest in far northeastern Siberia. In addition to examining effects of fire size and topography on post-fire larch aboveground biomass, we assessed regional fire rotation and density, as well as performance of burned area maps generated from MODIS satellite imagery. Using Landsat imagery, we mapped 116 fire scar perimeters that dated c. 1966-2007. We then mapped larch aboveground biomass by linking field biomass measurements to tree shadows mapped synergistically from WorldView-1 and Landsat 5 satellite imagery. Larch aboveground biomass tended to be low during early succession ( $\leq 25 \mathrm{yr}, 271 \pm 26 \mathrm{~g} \mathrm{~m}^{-2}$, $n=66$ [mean $\pm \mathrm{SE}]$ ) and decreased with increasing elevation and northwardly aspect. Larch aboveground biomass tended to be higher during mid-succession (33-38 yr, $746 \pm$ $100 \mathrm{~g} \mathrm{~m}^{-2}, n=32$ ), though was highly variable. The high variability was not associated with topography and potentially reflected differences in post-fire density of tree regrowth. Neither fire size nor latitude were significant predictors of post-fire larch aboveground biomass. Fire activity was considerably higher in the Kolyma Mountains (fire rotation $=110 \mathrm{yr}$, fire density $=1.0 \pm 1.0$ fires $\mathrm{yr}^{-1} \times 10^{4} \mathrm{~km}^{-2}$ )
\end{abstract}

than along the forest-tundra border (fire rotation $=792 \mathrm{yr}$, fire density $=0.3 \pm 0.3$ fires $\mathrm{yr}^{-1} \times 10^{4} \mathrm{~km}^{-2}$ ). The MODIS burned area maps underestimated the total area burned in this region from 2000-2007 by $40 \%$. Tree shadows mapped jointly using high and medium resolution satellite imagery were strongly associated $\left(r^{2} \approx 0.9\right)$ with field measurements of forest structure, which permitted spatial extrapolation of aboveground biomass to a regional extent. Better understanding of forest biomass distribution, disturbances and postdisturbance recovery is needed to improve predictions of the net climatic feedbacks associated with landscape-scale forest disturbances in northern Eurasia.

\section{Introduction}

Forests in the Russian Federation cover approximately 800 million ha and contain the largest vegetation carbon pool outside of the tropics (Goodale et al., 2002; Houghton et al., 2007) which, along with their low surface albedo, make them an important component of Earth's climate system (Bonan, 2008). Since instrumentation began in the 1880 s, average winter and summer air temperatures across northern Eurasia have risen $2{ }^{\circ} \mathrm{C}$ and $1.35^{\circ} \mathrm{C}$, respectively (Groisman and Soja, 2009), and climate models predict a $3-7^{\circ} \mathrm{C}$ increase in mean annual temperature across much of the region by the end of the 21st century (IPCC, 2007). Higher temperatures, with little or no change in precipitation, have resulted in drier conditions and increased risk of fire across much of 
the larch (Larix spp.) dominated boreal forests of Siberia (Groisman et al., 2007). While the boreal forest biome of northern Eurasia acts as a net sink for atmospheric $\mathrm{CO}_{2}$ (Goodale et al., 2002), the strength of this terrestrial carbon sink has weakened over the last decade due to increased fire emissions and warming-induced increases in decomposition of soil organic matter (Hayes et al., 2011). The strength of the sink will likely continue to diminish because rising air temperatures are expected to further increase fire activity (Stocks et al., 1998). Climate-induced intensification of the fire regime will affect forest carbon pools, surface energy budgets and hydrologic processes, yet the net effect of these feedbacks on the climate system remains poorly understood (Goetz et al., 2007; Bonan, 2008).

Fire is a dominant control on stand structure and composition in Siberian forests, with stand-replacing fires punctuating the start and end of successional cycles (Furyaev et al., 2001; Schulze et al., 2012). The accumulation of carbon after fire disturbance in Siberia's larch forests depends on characteristics of the fire regime, tree biology and site-level conditions, but details of these interactions are not fully understood, particularly in the northeastern permafrost zone (Kajimoto et al., 2010). Larch reestablishment and biomass accumulation depends on nonlinear interactions among fire periodicity and severity (Furyaev et al., 2001; Schulze et al., 2012), climate conditions (James, 2011; Lloyd et al., 2011), site micro-topography and permafrost (Koike et al., 2010; Zyryanova et al., 2010) and availability of seeds (Abaimov et al., 2000; Sofronov and Volokitina, 2010). Fire frequency (e.g., fire rotation or fire return interval), which is the interval of time between successive disturbances, averages around $80 \mathrm{yr}$ in northern larch forests, though exhibits considerable topographic and regional variability (Furyaev et al., 2001; Kharuk et al., 2011). If successive larch cohorts are destroyed by fire prior to reaching maturity and outside seed sources are not available, then forests can convert to nonarboreal vegetation (Sofronov and Volokitina, 2010). Alternatively, very infrequent fires in northern Siberia can lead to the long-term accumulation of moss and duff, which can block seedling establishment and cause larch forests to convert to tundra (Sofronov and Volokitina, 2010). Periodic fires, thus, help maintain larch forests and associated floristic diversity (Zyryanova et al., 2010; Schulze et al., 2012), though the affects of individual fires depends largely on fire severity.

Given Russia's size, low population density and logistical challenges associated with accessing fires, there is limited information on fire location, frequency, size and severity (Conard and Ivanova, 1997; Sukhinin et al., 2004). The federal government historically monitored and selectively suppressed fires across approximately $60 \%$ of forested lands, however, economic instability in the 1990s and early 2000 s led to a reduction fire suppression and monitoring activities (Sukhinin et al., 2004). The northern open woodlands of Siberia have always fallen outside of the protected zone and, thus, little is known about fire regime in this expansive region (Sofronov and Volokitina, 2010). Analysis of satellite imagery has helped shed light on spatial and temporal fire dynamics across the country; however, regional fire mapping has primarily focused on central Siberia (Kovacs et al., 2004; George et al., 2006; Sofronov and Volokitina, 2010). Fire mapping at national (Soja et al., 2004; Sukhinin et al., 2004; Soja et al., 2006) to supranational (Roy et al., 2005, 2008) scales has also been carried out, though these efforts relied on medium to coarse resolution imagery (e.g., MODIS and AVHRR). Fire maps created from coarse resolution imagery across broad spatial scales require external validation using higher resolution datasets (e.g., Landsat), though these independent fire records are often quite limited in availability (Roy et al., 2008). In spite of their limitations, Earth observing satellites are powerful tools that can help improve our understanding of fire dynamics in remote regions such as Russia's boreal forest.

For similar reasons, as Russia's fire regimes are not well understood, there is considerable uncertainty in the magnitude and distribution of Russia's forest carbon stocks. Published estimates of biomass in Russia's forests range from 46-148 Pg (Goodale et al., 2002; Houghton et al., 2007). Satellite analysis has helped improve our understanding of the distribution of forest biomass; however, since no satellites directly measure biomass, it is necessary to derive surrogate variables from satellite data that can be linked with field measurements (Baccini et al., 2012). Efforts to model forest biomass distribution by linking field and satellite measurements have met with mixed success in the boreal biome (Houghton et al., 2007; Fuchs et al., 2009; Leboeuf et al., 2012). Quantifying climate impacts associated with forest disturbances in Siberia necessitates understanding forest biomass distribution, disturbance regimes and post-disturbance ecosystem recovery; however, there is considerable uncertainty in each of these areas.

Our primary objective here was to improve our understanding of landscape-level carbon cycling dynamics following fire in the Cajander larch forests of northeastern Siberia. We focused on quantifying aboveground tree biomass (AGB) because trees drive much of the landscape-level variability in AGB in this ecosystem. For instance, trees in this region can account for over $95 \%$ of total stand AGB (Alexander et al., 2012). We examined trajectories of larch AGB accumulation following fire and how accumulation was affected by fire size and topography. To accomplish this, we conducted a geospatial analysis using satellite imagery from multiple sensors to map larch AGB and fire scars (c. 1966-2007) across approximately $100000 \mathrm{~km}^{2}$ of the Kolyma River watershed. Secondary objectives included quantifying fire rotation, fire density and fire-size distribution, as well as evaluating regional performance of the global MODIS burned area product (MCD45A1) (Roy et al., 2005, 2008), based on fires mapped from $30 \mathrm{~m}$ resolution Landsat imagery. We also devised a technique to map regional AGB by linking field measurements of AGB to tree shadows that were synergistically 
mapped using high $(50 \mathrm{~cm})$ and medium $(30 \mathrm{~m})$ spatial resolution satellite imagery. In addition to AGB, we assessed the relationships among tree shadows and canopy cover, tree height and tree density.

\section{Materials and methods}

\subsection{Study area}

The study area covered approximately $100000 \mathrm{~km}^{2}$ of the Kolyma River watershed in far northeastern Russian (Fig. 1). The region is underlain by continuous permafrost and has a cold, dry and continental climate. Annual air temperature averages $-12.5^{\circ} \mathrm{C}$, though average daily temperatures range from $-40^{\circ} \mathrm{C}$ to $+13{ }^{\circ} \mathrm{C}$. Precipitation averages 200 $215 \mathrm{~mm} \mathrm{yr}^{-1}$ and total summer evaporation is twice as high as summer precipitation (Corradi et al., 2005). Global climate models predict a $15-20 \%$ increase in precipitation across the region by the end of the 21st century (IPCC, 2007).

Cajander larch is the only tree species in our study area and dominates the permafrost zone from the Lena River in Central Yakutia to the Sea of Okhost in the Far East (Krestov, 2003; Abaimov, 2010). Cajander larch are a shadeintolerant deciduous needleleaf conifer capable of growing on permafrost and withstanding very short, cool growing seasons (Abaimov et al., 2000). In northeastern Siberia these trees are generally $<10 \mathrm{~m}$ tall and AGB rarely exceeds $10 \mathrm{~kg} \mathrm{~m}^{-2}$ (Kajimoto et al., 2010). Trees can annually produce up to $65 \mathrm{~kg} \mathrm{ha}^{-1}$ of wind-dispersed seeds (Abaimov, 2010). Forest succession after stand replacing fires generally involves a multi-decadal shrub stage, followed by larch re-achieving dominance $20-50 \mathrm{yr}$ after fire (Zyryanova et al., 2007; Alexander et al., 2012). Deciduous shrubs in the region include, though are not limited to, willow (Salix pulchra, S. alaxensis, and S. glauca), birch (Betula divaricata and B. exilis) and alder (Alnus fruticosa), while evergreen shrubs include Siberian dwarf pine (Pinus pumila), cowberry (Vaccinium vitis-idaea), dwarf Labrador tea (Ledum decumbens), and large-flowered wintergreen (Pyrola grandiflora) (Petrovsky and Koroleva, 1979).

\subsection{Satellite and geospatial data}

Our analysis made use of reflectance data from the WorldView-1 and Landsat series of satellites (Table 1). As part of the biomass mapping process, we used panchromatic WorldView-1 images with a nadir spatial resolution of $50 \mathrm{~cm}$ that were provided by the University of Minnesota Polar Geospatial Center. The seven images, which covered approximately $2150 \mathrm{~km}^{2}$, were acquired at local noon on 21 April 2009, with an average off nadir view angle of $2^{\circ}$ (Fig. 2b, c). On the day that the WorldView-1 images were acquired, snow depth near Cherskii was approximately $56 \mathrm{~cm}$ (Davydov, unpublished data). We mapped AGB and fire scars across approximately $100000 \mathrm{~km}^{2}$ using $30 \mathrm{~m}$ resolu-

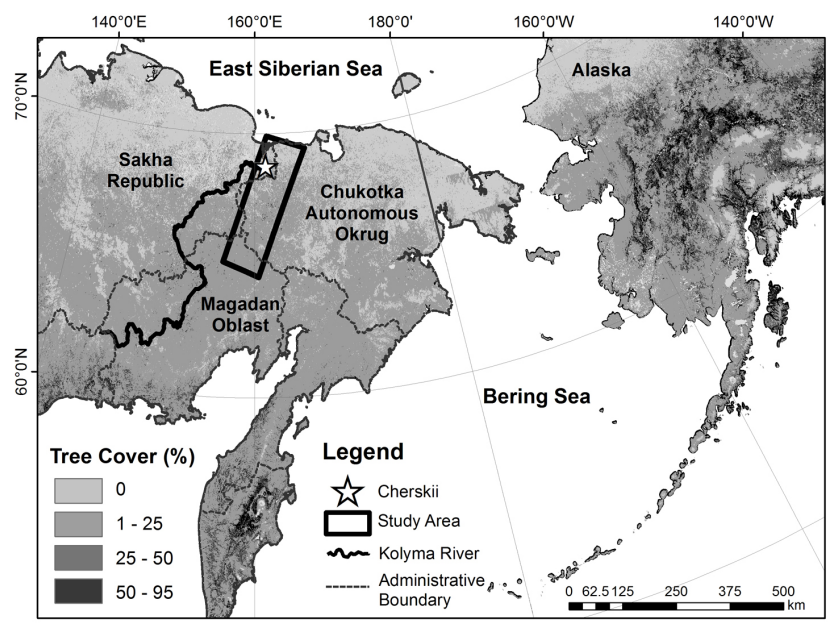

Fig. 1. Study area map of the lower Kolyma River watershed, which feeds into the East Siberian Sea in the Russian Far East. The study area spanned approximately $100000 \mathrm{~km}^{2}$ of open larch forest that transitioned into tundra along the northern edge.

tion Landsat images (WRS-2, path 104, rows 11-14; Table 1; Fig. 2a, d) provided by the United Stated Geological Survey Earth Resources Observation and Science Center. Biomass mapping was based on four along-track Landsat 5 scenes acquired on 26 July 2007. These were the most recent cloudand smoke-free images available for the region and defined the spatial extent of the study area. Though mapping AGB using Landsat imagery acquired during periods with snow cover has yielded better results than using snow-free images (Wolter et al., 2012), we were unable to find winter imagery of our study area through either the USGS (http://glovis.usgs. gov/) or NASA (http://reverb.echo.nasa.gov/) and, therefore, used images acquired during summer.

Fire scar mapping was based on 59 Landsat scenes that were acquired either 1972-1974 $(n=12)$ or 1995-2007 $(n=$ 47). Landsat data are not available from 1975-1995 (hereafter referred to as "Landsat blackout period") across eastern Siberia because there were no operational ground receiving stations. Furthermore, there were no Landsat images available for the southernmost quarter of the study area (path 104, row 14) until 1999. The Landsat images that we used to map fires were acquired between June and September, preferentially under cloud-free conditions late in the growing season. While WorldView-1 and Landsat reflectance data formed the basis of our analysis, we augmented the analysis with ancillary geospatial datasets.

The six ancillary geospatial datasets included models of topography, burned area, climate, vegetation productivity and tree canopy cover (Table 1). The topography dataset was the 1 arc-second $(\sim 30 \mathrm{~m})$ digital elevation model (DEM) generated by the Japanese Ministry of Economy, Trade and Industry and NASA from Advanced Spaceborne Thermal Emission and Reflection Radiometer data (ASTER GDEM 


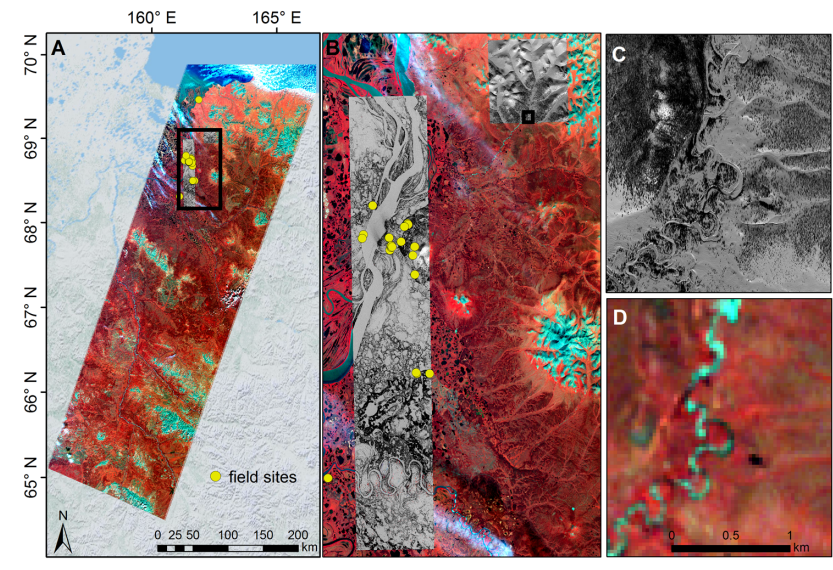

Fig. 2. Maps of the northeastern portion of the Kolyma River watershed showing the field sampling locations, as well as the (a) Landsat 5 and (b) WorldView-1 satellite imagery used in the analysis. To illustrate the large difference in spatial resolution between sensors, Fig. 2c, d show close-up views for WorldView-1 and Landsat 5, respectively. The Landsat 5 imagery is displayed using bands 4, 3, 1 (RGB).

v2) (Meyer et al., 2011). The burned area dataset, which spanned 2000-2007, was the $500 \mathrm{~m}$ monthly burned area product (MCD43A1 v5) generated from Moderate Resolution Imaging Spectroradiometer (MODIS) sensors carried aboard NASA's Aqua and Terra satellites. The gridded climate data included monthly averages of temperature and precipitation that were produced by the University of East Anglia Climate Research Unit (CRU v3.1) at $0.5^{\circ}$ resolution from climate station data. As a proxy for vegetation productivity, we used a normalised difference vegetation index (NDVI) dataset generated from Advanced Very High Resolution Radiometer (AVHRR) data by NASA's Global Inventory Modelling and Mapping Studies (GIMMS v3G) project (Tucker et al., 2005). This $8 \mathrm{~km}$ resolution biweekly dataset runs from 1981 through to the present. The final two datasets included the MODIS vegetation continuous fields product (MODIS VCF v5; MOD44B) (Hansen et al., 2003), which mapped global tree canopy cover (TCC) at $250 \mathrm{~m}$ resolution, and the related TCC map generated by Ranson et al. (2011) from MODIS VCF (v4) in an effort to improve TCC estimates along the circumpolar taiga-tundra ecotone.

\subsection{Field measurements of aboveground biomass}

Fieldwork was conducted near Cherskii, in the Sakha Republic (Yakutia), though the study area also included portions of the more mountainous Chukotka Autonomous Okrug and the Magadan Oblast (Fig. 2a). Field data used in this study were collected during July 2010 and 2011 at 25 sites. In 2010, Alexander et al. (2012) inventoried 17 Cajander larch sites and in 2011 Bunn and Frey (unpublished) inventoried eight additional sites. Field estimates of larch aboveground biomass $\left(\mathrm{AGB}_{\text {field }}\right)$ were derived from allometric equations that related diameter at breast height or basal diameter to

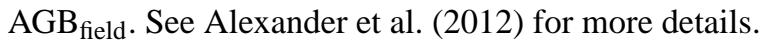

\subsection{Satellite image preprocessing}

The four Landsat scenes used for biomass mapping were converted from surface radiance to top of atmosphere reflectance using the Landsat calibration tool in ENVI (ITT Visual Information Solutions, v4.8). We then masked water bodies, clouds, cloud shadows and steep north-facing slopes where shadows obscured underlying vegetation. Water bodies were identified using a 30-class isodata unsupervised clustering algorithm with a minimum class-size of 20 pixels and then buffered one pixel outward to ensure complete removal. Clouds and cloud shadows were manually delineated and excluded. Shadowed northern slopes were removed based on topography by selecting areas with slope $>15^{\circ}$ and aspect either $>270^{\circ}$ or $<45^{\circ}$. Landsat preprocessing resulted in a radiometrically calibrated image mosaic void of water bodies, clouds and areas shaded by clouds and mountains.

The WorldView-1 images came orthorectified and calibrated to top of atmosphere reflectance. We mosaiced the six contiguous images and then co-registered the WorldView-1 mosaic to the Landsat mosaic to ensure proper geographical overlap. Co-registration involved identifying 50 matching points and then warping the WorldView-1 mosaic using a first-order polynomial $(\mathrm{RMSE}=16.7 \mathrm{~m})$. It was not necessary to adjust the georeferencing of the single noncontiguous WorldView-1 scene (Fig. 2b). We applied the Landsat water mask and the topography shadow mask and then digitised and removed two small urban zones from the analysis.

\subsection{Aboveground biomass mapping}

We used a combination of multi-sensor satellite imagery and field measurements to map AGB across the study area. This involved first using WorldView-1 to map tree shadow fraction $\left(\mathrm{TSF}_{\mathrm{WV}}\right.$ ) as a surrogate for AGB and then using these

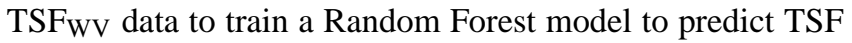
across a Landsat mosaic $\left(\mathrm{TSF}_{\mathrm{LS}}\right)$ that covered an area about 50 times that of the WorldView-1 scenes. We then linearly transformed the $\mathrm{TSF}_{\mathrm{LS}}$ map into a map of AGB (AGB $\left.\mathrm{AS}_{\mathrm{L}}\right)$ using a regression equation derived by comparing $\mathrm{TSF}_{\mathrm{LS}}$ and $\mathrm{AGB}_{\text {field }}$.

Individual trees and tree shadows contrasted sharply with the bright, snow-covered land surface in the WorldView1 images. After testing a series of threshold values, we classified pixels as tree shadow if reflectance was between 0.17 and 0.37 . This resulted in a $50 \mathrm{~cm}$ resolution binary map showing tree shadow and non-tree shadow. The tree shadow map was then aggregated to $30 \mathrm{~m}$ resolution to match the footprint of the Landsat mosaic. Aggregation involved 
Table 1. Details of the satellite imagery and ancillary geospatial datasets that we used for mapping and analysing larch biomass distribution, forest fires and forest biomass recovery after fire in northeastern Siberia.

\begin{tabular}{|c|c|c|c|c|}
\hline Use & $\begin{array}{l}\text { Satellite } \\
\text { or Dataset }\end{array}$ & $\begin{array}{l}\text { Data } \\
\text { Acquisition }\end{array}$ & $\begin{array}{l}\text { Scenes } \\
(n)\end{array}$ & $\begin{array}{l}\text { Resolution } \\
(m)\end{array}$ \\
\hline Biomass & WorldView-1 & 21 April 2009 & 7 & 0.5 \\
\hline Mapping & Landsat 5 TM & 26 July 2007 & 4 & 30 \\
\hline \multirow{4}{*}{$\begin{array}{l}\text { Fire Scar } \\
\text { Mapping }\end{array}$} & Landsat 7 ETM+ & 1999-2004 & 26 & 30 \\
\hline & Landsat $5 \mathrm{TM}$ & $\begin{array}{l}1995,2005 \\
2006,2007\end{array}$ & 21 & 30 \\
\hline & Landsat $1-3$ MSS & 1972-1974 & 12 & 79 \\
\hline & Total & $1972-2007$ & 59 & - \\
\hline \multirow[t]{5}{*}{$\begin{array}{l}\text { Ancillary } \\
\text { Datasets }\end{array}$} & $\begin{array}{l}\text { Digital Elevation Model } \\
\text { (ASTER) }\end{array}$ & $\begin{array}{l}\text { Composite } \\
2000-2008+\end{array}$ & 1 & 30 \\
\hline & $\begin{array}{l}\text { Tree Canopy Cover } \\
\text { (MODIS) }\end{array}$ & $\begin{array}{l}2010 \\
\text { Composite } \\
2000-2005\end{array}$ & $\begin{array}{l}1 \\
1\end{array}$ & $\begin{array}{l}250 \\
500\end{array}$ \\
\hline & $\begin{array}{l}\text { Burned Area } \\
\text { (MODIS) }\end{array}$ & $\begin{array}{l}\text { Monthly } \\
\text { 2000-2007 }\end{array}$ & 96 & 500 \\
\hline & $\begin{array}{l}\text { NDVI } \\
\text { (GIMMS AVHRR) }\end{array}$ & $\begin{array}{l}\text { Biweekly } \\
\text { 1981-2007 }\end{array}$ & 636 & $8 \times 10^{3}$ \\
\hline & CRU Climate ( $\mathrm{T}$ and PPT) & $\begin{array}{l}\text { Monthly } \\
1901-2007\end{array}$ & 1284 & $55 \times 10^{3}$ \\
\hline
\end{tabular}

calculating the percent of each $30 \times 30 \mathrm{~m}$ pixel that was classified as tree shadow. We defined this value as TSF $\mathrm{Wv}$. The impact of variation in sun angle on $\mathrm{TSF}_{\mathrm{WV}}$ was assumed to be minimal because the WorldView-1 images were all acquired on the same day at local noon and since Leboeuf et al. (2007) showed that normalising TSF based on sun and sensor geometry had a non-discernible impact on the relationship between TSF and field biomass measurements. Variation in snow depth was also assumed to have a negligible effect on $\mathrm{TSF}_{\mathrm{WV}}$ due to the minimal topographic relief in the area. Following the calculation of $\mathrm{TSF}_{\mathrm{WV}}$, we randomly selected 2500 points that were spaced at least $30 \mathrm{~m}$ apart and which were stratified by three $\mathrm{TSF}_{\mathrm{Wv}}$ classes $(0-1 \%$, $1-30 \%$, and $30-100 \%)$. The underlying TSF pixel values were then extracted and used to train $(n=2000)$ and evaluate $(n=500)$ a Random Forest model that predicted $\mathrm{TSF}_{\mathrm{LS}}$ from the Landsat data.

We used a combination of Landsat reflectance values and band metrics (e.g., NDVI) as predictor data for the Random Forest model (See Table 3 in Results for details). Random Forests are a form of classification and regression analysis where many decision trees are constructed using bootstrap sampling, with the final prediction determined based upon "votes" cast by each tree (Breiman, 2001). This machine learning technique can efficiently process large datasets, has low bias, and tends not to over fit models (Breiman, 2001). We used the randomForest package (Liaw and Wiener, 2002) in R (R Development Core Team, 2011) to build 500 decision trees, with five predictor variables randomly selected and tested at each node of each tree. Model performance was evaluated by regressing $\mathrm{TSF}_{\mathrm{LS}}$ by $\mathrm{TSF}_{\mathrm{WV}}$ for 500 points not used in model construction. The calibrated Random Forest model yielded a map of $\mathrm{TSF}_{\mathrm{LS}}$ that we then compared with $\mathrm{AGB}_{\text {field }}$ measurements from 25 sites. We calculated mean $\mathrm{TSF}_{\mathrm{LS}}$ and $\mathrm{TSF}_{\mathrm{WV}}$ ( \pm standard error) within a $30 \mathrm{~m}$ diameter buffer zone centred on the mid-point of each transect and then used least-squared linear regression with the intercept forced through zero to evaluate the relationship between $\mathrm{AGB}_{\text {field }}$ and both $\mathrm{TSF}_{\mathrm{LS}}$ and TSF $\mathrm{WV}$. The regression intercept was forced through zero so that treeless areas, such as alpine or tundra, could be modelled as having no tree AGB. The regression equation was then used to transform the map of TSF $F_{L S}$ into a map of $A_{G B}$. We compared this map of $\mathrm{AGB}_{\mathrm{LS}}$ with the MODIS tree canopy cover products by resampling all to $500 \mathrm{~m}$ resolution and running Pearson's correlations on 5000 random points. We also compared $\mathrm{TSF}_{\mathrm{LS}}$ and $\mathrm{TSF}_{\mathrm{WV}}$ with field measurements of canopy cover, tree height and tree density using Pearson's correlations.

\subsection{Fire scar mapping}

The 59 Landsat images were first sorted into four regions based on the WRS-2 grid (path 104, rows 11-14). Each stack of images was then visually inspected in chronological order. 
We used false-colour images, along with the normalised burn ratio (NBR) and NDVI to identify fire scars. The band combinations 7-5-2 (L5 and L7) and 3-4-2 (L1-L3) proved useful for identifying fire scars, as were the band metrics, which were calculated as NDVI $=\left(R_{\mathrm{NIR}}-R_{\text {red }}\right) /\left(R_{\mathrm{NIR}}+R_{\text {red }}\right)$ and $\mathrm{NBR}=\left(R_{\mathrm{NIR}}-R_{\mathrm{SWIR}}\right) /\left(R_{\mathrm{NIR}}+R_{\mathrm{SWIR}}\right)$. We hand-digitised fire scar perimeters at a scale of $1: 150000$ or $1: 60000$, depending on the fire size and perimeter complexity, and then spatially adjusted the fire scar perimeters to align with the Landsat 5 image used to map biomass.

For each fire scar, we determined the period of time during which the fire occurred by recording the year of the prefire and post-fire Landsat images. For fires that occurred between 2000-2007, we used the MODIS burned area product (MCD45A1) to identify the year of burn when possible. We dated large fires that occurred between 1981-2000 by using GIMMS-NDVI to identify when NDVI rapidly dropped and stayed low relative to surrounding areas. We estimated the burn year when smoke trails were not visible and when it was not possible to date fires based on MODIS or GIMMS. Fire scars were generally visible in NIR for about six years following fire. For fresh fire scars visible in the earliest available imagery, or immediately after the Landsat blackout period, we estimated the fires had occurred anytime during the preceding 6 yr. If fires occurred during the Landsat blackout period, but were not visible in post-1995 NIR imagery, we estimated that they occurred during the 1980s.

After mapping and dating fire scars, we derived descriptors of the fire regime (fire rotation, fire density, and fire size distribution) and then examined the relationships among fire activity and both mean monthly air temperatures and precipitation. Fire rotation is the average number of years necessary to burn an area equivalent in size to the area of interest and is calculated by dividing the time period by the fraction of the landscape that burned during that period (Heinselman, 1973). Fire rotation is equivalent to fire return interval, which is a point-specific estimate of the average time between two successive fire events, when every point on the landscape has an equal probability of burning. We calculated fire density as the number of fire scars formed in a given year divided by the area over which they occurred. Defining fire density based on fire scars likely underestimates the true number of discrete fire events, as large fire scars in Siberia sometimes result from multiple fire events merging during the fire season (Loboda and Csiszar, 2007). Since the spatial coverage of Landsat imagery was incomplete across the southern quarter of the study area prior to 1999 , we calculated fire rotation and density across the northern three quarters for c. 19662007 (66.0-69.5 $\mathrm{N}$, WRS-2 path 104, rows 11-13). In basing these calculations on the c. 1966-2007 time period, we are assuming that fires visible in the 1972 imagery occurred within the preceding six years. Due to greater availability of Landsat imagery and to the MODIS burned area product, our fire record was most accurate and spatially complete from 2000-2007. As such, we used fire scars from this time period to examine differences in fire activity between the open larch forests of the Kolyma Mountains (64.5-67.0 $0^{\circ} \mathrm{N}$ ) and the lowland forest-tundra zone $\left(67.0-69.5^{\circ} \mathrm{N}\right)$. We also used fire scars from 2000-2007 to examine the associations among annual fire activity (area burned, number of fires and mean fire size) and climate (mean monthly temperature and precipitation).

\subsection{Accumulation of aboveground biomass following fire}

To assess larch regrowth following fire, we quantified AGB across fire scars that ranged in time since last fire from 3$38 \mathrm{yr}$ and then examined whether fire size, latitude, elevation or aspect affected regrowth. Our analysis was restricted to fires that burned c. 1969-2005 because the AGB model predicted erroneously high values for fires that had burned within two years of the Landsat data acquisitions. Fire scars that were visible in the NIR band in the 1972 imagery were dated as having occurred, at the earliest, in $1969 \pm 3 \mathrm{yr}$. To determine whether AGB accumulated linearly through time, we used piecewise linear regression to model median fire scar AGB as a function of time. Robust linear regression, as implemented via rlm in the R MASS package (Venables and Ripley, 2002), was then used to estimate the AGB accumulation rate for early successional $(\leq 25 \mathrm{yr})$ and midsuccessional $(33-38 \mathrm{yr})$ fire scars. There were no fires in the 26 to 32 age range. We then used least-squared multiple linear regression to determine whether fire size, latitude and their interactions with fire age could predict median fire scar AGB. Since AGB accumulation within an individual fire scar could vary depending on landscape position and microclimate, we used linear mixed models to investigate the controls of elevation and aspect on rates of AGB accumulation for early and mid-successional fire scars. Aspect was cosine-transformed to quantify the degree of northward topographical exposure. The models were calibrated using 9750 grid cells randomly sampled within fire scars and included fire identity (i.e., a variable denoting to which fire a sample belonged) as a random effect to correct for repeated sampling within individual fires. Aboveground biomass values were log-transformed prior to inclusion in the mixed models to meet the assumptions of data normality and randomly distributed residuals. Full models, which included elevation, aspect, fire age and their interactions, were fitted first and then compared against simpler models using Akaike Information Criterion (Akaike, 1974) to statistically evaluate whether landscape position influenced post-fire AGB production. 


\section{Results}

\subsection{Mapping and distribution of larch aboveground biomass}

Validation of the Random Forest-generated $\mathrm{TSF}_{\mathrm{LS}}$ map showed that it agreed relatively well with the $\mathrm{TSF}_{\mathrm{WV}}$ map $\left(r^{2}=0.72, p<0.01, \mathrm{RMSE}=16.4 \%, n=500\right)$. Compared to $\mathrm{TSF}_{\mathrm{WV}}$, the model tended to under-predict $\mathrm{TSF}_{\mathrm{LS}}$ in areas of relatively dense forest and over-predict it in some areas of sparse tree cover. We observed a strong linear relationship between $\mathrm{AGB}_{\text {field }}$ and both $\mathrm{TSF}_{\mathrm{WV}}\left(r^{2}=0.90\right.$, RMSE $=722 \mathrm{~g} \mathrm{~m}^{-2}$, Fig. 3a) and model-predicted $\mathrm{TSF}_{\mathrm{LS}}$ $\left(r^{2}=0.91\right.$, RMSE $=622 \mathrm{~g} \mathrm{~m}^{-2}$, Fig. 3b $)$. Diagnostic plots showed that for $\mathrm{TSF}_{\mathrm{LS}}$ the residuals were randomly distributed and homoscedastic, while for $\mathrm{TSF}_{\mathrm{WV}}$ the residuals were skewed towards lower values. In addition to showing strong relationships with $\mathrm{AGB}_{\text {field }}$, TSF from both sensors exhibited strong correlations with canopy cover $(r \approx 0.88)$, moderate correlations with tree density $(r \approx 0.65)$ and weak correlations with tree height $(r \approx 0.40$; Table 2$)$. We found that $\mathrm{TSF}_{\mathrm{LS}}$ was a better proxy for $\mathrm{AGB}_{\text {field }}$ than any individual Landat band or band metric used as an input for the Random Forest model (Table 3). Of the Random Forest inputs, $\mathrm{AGB}_{\text {field }}$ was most strongly correlated with Landsat's short-wave infrared (SWIR, bands 7 and 5, $r=-0.82$ and 0.77) and red bands (band 3, $r=-0.77$ ) and exhibited the weakest correlations with the vegetation indices (Soil Adjusted Vegetation Index: $r=-0.04$, NDVI: $r=0.33$ ). The Random Forest identified Landsat's SWIR and red bands as the most important predictors of $\mathrm{TSF}_{\mathrm{LS}}$, as these inputs yielded the largest mean decrease in node impurity (sensu Breiman, 2001; Table 3). By linking field biomass measurements with tree shadows mapped at a high spatial resolution and then modelled across a broad regional extent, we were able to characterise the spatial distribution of AGB across the study area.

Larch stands are very heterogeneously distributed across the forest-tundra ecotone in far northeastern Siberia, with the distribution of AGB reflecting the combined influences of climate, topography and past disturbances (Fig. 4a). Latitudinal tree line occurred at around $69.07^{\circ} \mathrm{N}$, while altitudinal tree line decreased from around $780 \mathrm{~m}$ a.s.l. in the central Kolyma Mountains $\left(\sim 65^{\circ} \mathrm{N}\right)$ to around $400 \mathrm{~m}$ a.s.l. along the foresttundra border $\left(\sim 69^{\circ} \mathrm{N}\right)$. The $\mathrm{AGB}_{\mathrm{LS}}$ map captured the altitudinal transition from forest to alpine, as well as the latitudinal transition from forest to tundra. In areas with no recent fire activity, $\mathrm{AGB}_{\mathrm{LS}}$ averaged $1156 \mathrm{~g} \mathrm{~m}^{-2}$, though ranged from 0.3 to $6703 \mathrm{~g} \mathrm{~m}^{-2}$. Aboveground biomass exceeded $1882 \mathrm{~g} \mathrm{~m}^{-2}$ across only $25 \%$ of the landscape (Fig. 5). We found that the landscape distribution of $A_{G B}$ LS showed similar patterns to tree canopy cover mapped from MODIS imagery, though our map captured much finer spatial variability in forest distribution than did the MODIS products. Our map of $\mathrm{AGB}_{\mathrm{LS}}$ exhibited moderately strong correlations with both
Table 2. Pearson's correlations among field measurements of forest structure and tree shadow fraction mapped from WorldView-1 $(n=$ $22)$ and Landsat $5(n=25)$. Correlation coefficients $(r)$ in bold are significant at $\alpha<0.05$.

\begin{tabular}{lll}
\hline Stand Measurement & \multicolumn{2}{c}{ Tree Shadow Fraction } \\
\cline { 2 - 3 } & WorldView-1 & Landsat 5 \\
\hline Aboveground Biomass & $\mathbf{0 . 9 2}$ & $\mathbf{0 . 9 1}$ \\
Canopy Cover & $\mathbf{0 . 8 9}$ & $\mathbf{0 . 8 8}$ \\
Tree Density & $\mathbf{0 . 7 1}$ & $\mathbf{0 . 5 4}$ \\
Tree Height & 0.39 & $\mathbf{0 . 4 1}$ \\
\hline
\end{tabular}

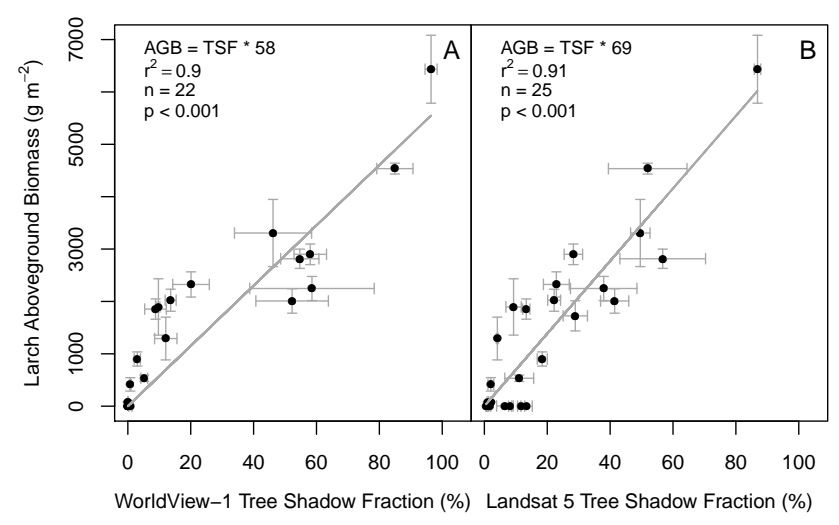

Fig. 3. Comparison of aboveground biomass from field estimates $\left(\mathrm{AGB}_{\text {field }}\right)$ with tree shadow fraction (TSF) derived from (a) WorldView-1 and (b) Landsat 5 satellite images. The points represent site means $( \pm 1$ standard error). The relationship between $\mathrm{AGB}_{\text {field }}$ and TSF is highly significant for both sensors $\left(r^{2} \approx 0.90\right.$, $p<0.001)$

MODIS VCF $(r=0.76, p<0.001, n=5000)$ and MODIS TCC $(r=0.81, p<0.001, n=5000)$. Forest patches of relatively high $\mathrm{AGB}_{\mathrm{LS}}$ occurred along upland hill slopes, between braided streams and on elevated hills in the wet Kolyma Lowlands. Within the forested zone, stand biomass and distribution strongly reflected the influence of past fires.

\subsection{Fires in the northeastern kolyma river watershed}

We mapped 116 fires that burned between c. 1966-2007 across $14778 \mathrm{~km}^{2}(14.1 \%)$ of the northeastern portion of the Kolyma River watershed (Figs. $4 \mathrm{~b}$ and 6 ). We are confident in having correctly identified the burn year for $59 \%(n=68)$ of these fires, while for $38 \%(n=44)$ of the fires we estimated the potential dating error to vary from half a year to two years. For the remaining $3 \%(n=4)$ of fire scars, the potential dating error ranged from three to eight years. Due to potential dating errors, the annual number of fires and area burned, as shown in Fig. 6, should be viewed as best approximations that are most accurate from 2000-2007.

Though there was some uncertainty in dating fire scars, fire activity exhibited considerable interannual variability. 
Table 3. Landsat 5 indices used as predictor variables with the Random Forest algorithm to model tree shadow fraction. Pearson's correlation $(r)$ with aboveground biomass and the mean decrease in node purity, a Random Forest generated metric of variable importance, are provided for each predictor variable. Correlations in bold are significant at $\alpha<0.05$.

\begin{tabular}{lrr}
\hline $\begin{array}{l}\text { Landsat 5 } \\
\text { variable }\end{array}$ & $\begin{array}{r}\text { Correlation } \\
\text { with AGB }(r)\end{array}$ & $\begin{array}{r}\text { Mean decrease } \\
\text { in node impurity }\end{array}$ \\
\hline Tree shadow fraction & $\mathbf{0 . 9 1}$ & NA \\
Band 1 & $\mathbf{- 0 . 7 0}$ & 141167 \\
Band 2 & $-\mathbf{0 . 7 2}$ & 129733 \\
Band 3 & $-\mathbf{0 . 7 7}$ & 342318 \\
Band 4 & -0.31 & 36685 \\
Band 5 & $-\mathbf{0 . 7 7}$ & 316155 \\
Band 7 & $\mathbf{- 0 . 8 2}$ & 478976 \\
Bands 4/5 & $\mathbf{0 . 5 0}$ & 40621 \\
Bands 7/4 & $-\mathbf{0 . 4 1}$ & 50411 \\
Bands 7/5 & -0.34 & 47084 \\
NDVI & 0.33 & 41678 \\
SAVI & -0.04 & 31219 \\
NBR & $\mathbf{0 . 4 4}$ & 40307 \\
PCA I & $-\mathbf{0 . 6 0}$ & 92183 \\
PCA II & -0.37 & 28622 \\
PCA III & 0.30 & 51482 \\
\hline
\end{tabular}

Excluding the Landsat blackout period, the annual fire occurrence ranged from $0-22$ fires (median $=3$ fires $\mathrm{yr}^{-1}$ ) and the annual area burned ranged from $0-2296 \mathrm{~km}^{2}$ $\left(\right.$ median $\left.=119 \mathrm{~km}^{2} \mathrm{yr}^{-1}\right)$. The large burn years of 2001 (1762 km² burned) and $2003\left(2296 \mathrm{~km}^{2}\right.$ burned) contrasted sharply with the 2004-2007 period, during which the annual area burned averaged $111 \pm 64 \mathrm{~km}^{2}$ ( \pm standard error). Mean daily July air temperatures in $2001\left(14.4^{\circ} \mathrm{C}\right)$ and 2003 $\left(14.0^{\circ} \mathrm{C}\right)$ were the highest reported in the CRU record $(1901-$ 2009) and were about $2^{\circ} \mathrm{C}$ higher than the 2004-2007 average $\left(11.9 \pm 0.5^{\circ} \mathrm{C}\right)$. Summer (July-August) precipitation in $2001(79.6 \mathrm{~cm})$ and $2003(93.9 \mathrm{~cm})$ was about $20 \%$ lower than the 2004-2007 average $(108.2 \pm 9.0 \mathrm{~cm})$. July is the hottest month of the year and from 2000-2007 was the only month during which air temperature and annual fire activity exhibited statistically significant correlations $(\alpha=0.05, n=$ 8 ). Mean July air temperatures exhibited strong correlations with annual number of fires $(r=0.72), \log 10$-transformed area burned $(r=0.87)$, and $\log 10$-transformed mean annual fire size $(r=0.83)$. January was the only month during which fire activity and monthly precipitation were significantly correlated; however, we are inclined to believe this was a false positives due to precipitation in January generally accounting for less than $7 \%$ of the annual total. Fire size varied over five orders of magnitude, from $0.06-2570 \mathrm{~km}^{2}$ (median $=33 \mathrm{~km}^{2}$; Fig. 7), with the single largest fire scar accounting for $17 \%$ of the area burned over the $38 \mathrm{yr}$ period. The ten largest fires accounted for about $50 \%$ of the total burned area, while the largest $25 \%$ of fires (fires $>150 \mathrm{~km}^{2}$ )

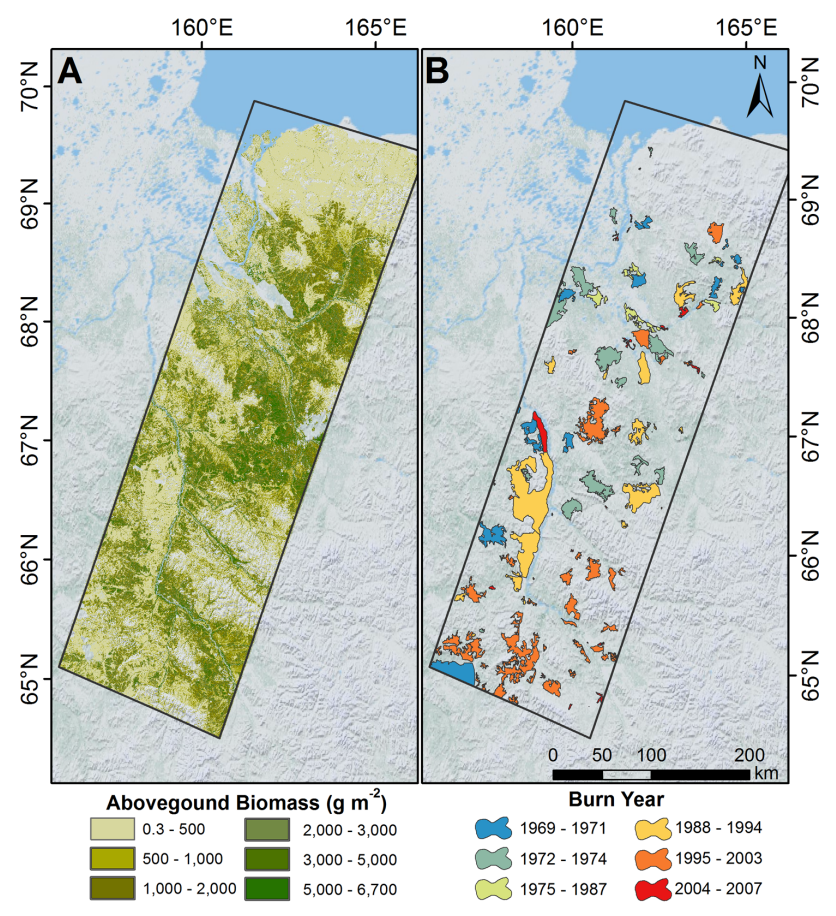

Fig. 4. Maps of the northeastern portion of the Kolyma River watershed showing (a) aboveground biomass of Cajander larch and (b) burn scar perimeters for fires that occurred c. 1969-2007. Both datasets were derived primarily from $30 \mathrm{~m}$ resolution Landsat imagery.

were responsible for $78 \%$ of the total area burned. Annual area burned, number of fires and fire size all varied widely and were positively associated with July air temperatures, with two of the largest burn years coinciding with the two hottest Julys over the $109 \mathrm{yr}$ record.

We quantified fire rotation and density using the fire scars mapped from Landsat and then examined regional differences in fire activity (Table 4). Across the northern three quarters of the study area $\left(66.0-69.5^{\circ} \mathrm{N}\right)$, we estimated fire activity using data covering both c. 1966-2007 and 20002007, which showed fire rotation to be 301-397 yr and fire density to be $0.3-0.2$ fires $\mathrm{yr}^{-1} \times 10^{4} \mathrm{~km}^{-2}$, respectively. Fire rotation and density were both about one third less when calculated using c. 1966-2007 data than when calculated using 2000-2007 data. Examining fire activity over this broad extent masked large regional differences between the Kolyma Mountains and the forest-tundra border. From 2000-2007, fire rotation was seven times shorter in the mountains than in the lowlands (110 vs. $792 \mathrm{yr})$ and fire density was three times greater $\left(1.0 \pm 1.0\right.$ vs. $0.3 \pm 0.3$ fires $\left.\mathrm{yr}^{-1} \times 10^{4} \mathrm{~km}^{-2}\right)$, highlighting pronounced regional differences.

We identified 59 fires in Landsat scenes that cumulatively burned $4731 \mathrm{~km}^{2}$ of the study area between $2000-2007$. The MODIS burned area product detected $44(74.6 \%)$ of these fires and mapped a total area burned of $2859 \mathrm{~km}^{2}$. Relative to our estimate, MODIS underestimated the total area burned 
Table 4. Summary of fire activity across $100000 \mathrm{~km}^{2}$ of the Kolyma River watershed in far northeastern Siberia. Annual area burned and fire density are annual means, with 25 th and 75 th percentiles to show skewness.

\begin{tabular}{|c|c|c|c|c|c|c|}
\hline \multirow{2}{*}{$\begin{array}{l}\text { Region of Study Area } \\
\text { and Time Period }\end{array}$} & \multirow{2}{*}{$\begin{array}{r}\text { Number of Fires } \\
(n)\end{array}$} & \multirow{2}{*}{$\begin{array}{r}\text { Total Area Burned } \\
\qquad\left(\mathrm{km}^{2}\right)\end{array}$} & \multicolumn{2}{|c|}{ Mean Annual Area Burned } & \multirow{2}{*}{$\begin{array}{r}\text { Fire } \\
\text { Rotation } \\
\text { (years) }\end{array}$} & \multirow{2}{*}{$\begin{array}{r}\text { Fire } \\
\text { Density } \\
\left(n \mathrm{yr}^{-1} \times 10^{4} \mathrm{~km}^{-2}\right)\end{array}$} \\
\hline & & & $\left(\mathrm{km}^{2}\right)$ & $(\%)$ & & \\
\hline northern $3 / 4$ & 70 & 10270 & 245 & 0.33 & 301 & 0.2 \\
\hline $\begin{array}{l}\text { c. } 1966-2007 \\
\text { northern } 3 / 4 \\
2000-2007\end{array}$ & 20 & 1482 & $185[0,145]$ & $0.25[0.00,0.20]$ & 397 & $0.3[0.0,0.6]$ \\
\hline $\begin{array}{l}\text { forest-tundra } \\
2000-2007\end{array}$ & 12 & 454 & $57[0,58]$ & $0.13[0.00,0.13]$ & 792 & $0.3[0.0,0.5]$ \\
\hline $\begin{array}{l}\text { mountain forest } \\
2000-2007\end{array}$ & 47 & 4277 & $535[42,601]$ & $0.91[0.07,1.03]$ & 110 & $1.0[0.3,1.1]$ \\
\hline
\end{tabular}

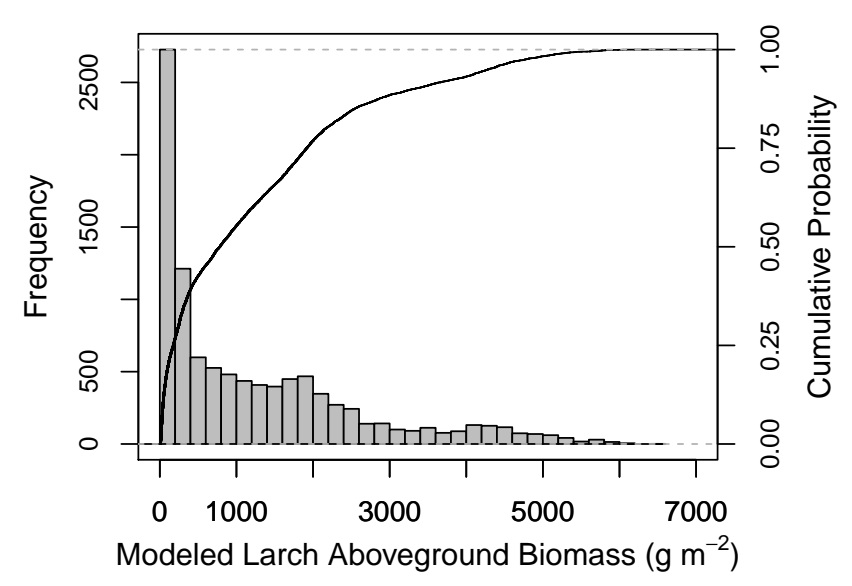

Fig. 5. Frequency and empirical cumulative distribution function plots of Cajander larch aboveground biomass modelled from Landsat 5 satellite imagery $\left(\mathrm{AGB}_{\mathrm{LS}}\right)$ in areas with no recent fire activity. Across the landscape, $\mathrm{AGB}_{\mathrm{LS}}$ ranged from 0.3 to $6703 \mathrm{~g} \mathrm{~m}^{-2}$, with $50 \%$ of areas having less than $748 \mathrm{~g} \mathrm{~m}^{-2}$.

by about $40 \%$, primarily as a result of underestimating the area burned by each fire. Importantly, MODIS detected the fires that were cumulatively responsible for $96 \%$ of the total area burned that we mapped from Landsat. The smallest fire detected was $1.7 \mathrm{~km}^{2}$, while the largest fire missed was $41.1 \mathrm{~km}^{2}$. Visual comparison of the fire maps showed that almost all of the MODIS single-pixel or small pixel-cluster burns were not actually fires. The larger burn scars identified in the MODIS product tended to be conservative areal estimates that captured the central region of the Landsat-mapped fires, though missed peripheral burned areas.

\subsection{Accumulation of larch aboveground biomass after fire}

For the 98 fires that burned between c. 1969-2005, the accumulation of larch AGB was strongly nonlinear through time (Fig. 8). This nonlinear AGB response to time was confirmed by piecewise linear regression. In comparison to a simple linear regression, using a two-segment regression with a breakpoint set between $26-34 \mathrm{yr}$ reduced the residual variance when modelling median fire-level AGB as a function of time $\left(148 \times 10^{5}\right.$ vs. $\left.162 \times 10^{5}\right)$. During early succession $(\leq 25 \mathrm{yr})$, AGB averaged $271 \pm 26 \mathrm{~g} \mathrm{~m}^{-2}(n=66, \pm$ standard error), but ranged from $31 \pm 45 \mathrm{~g} \mathrm{~m}^{-2}$ to $892 \pm 499 \mathrm{~g} \mathrm{~m}^{-2}$ (median \pm interquartile range). The rate of AGB accumulation during early succession appeared minimal when assessed using robust linear regression $\left(5.9 \pm 5.4 \mathrm{~g} \mathrm{~m}^{-2} \mathrm{yr}^{-1}\right.$, $n=66)$. There were no fires in the $26-32 \mathrm{yr}$ age range, which appeared to be an important transitional period after which AGB accumulation increased considerably. For midsuccessional stands that were 33-38 yr old, AGB averaged $746 \pm 100 \mathrm{~g} \mathrm{~m}^{-2}(n=32)$ and we estimated the rate of AGB accumulation to be $138 \pm 67 \mathrm{~g} \mathrm{~m}^{-2} \mathrm{yr}^{-1}$. Across these midsuccessional stands, larch AGB ranged from $126 \pm 46 \mathrm{~g} \mathrm{~m}^{-2}$ to $2212 \pm 2000 \mathrm{~g} \mathrm{~m}^{-2}$ (median \pm inter-quartile range). Larch AGB was generally low during the first $25 \mathrm{yr}$ and then exhibited rapid accumulation at some sites 33-38 yr following fire; however, regrowth was highly variable and some fire scars showed little AGB accumulation after nearly four decades.

Accumulation of larch AGB after fire was not associated with fire size or latitude, though in the early successional stands it declined with both increased elevation and northwardly aspect. Neither fire size, latitude, nor their interactions with fire age were significant predictors $(p>0.05)$ of median larch AGB for early ( $\leq 25 \mathrm{yr}, n=66)$ or midsuccessional (33-38 yr, $n=32$ ) stands, as assessed using multiple linear regression. The mixed linear model showed that for early successional stands larch AGB accumulation decreased with elevation $\left(p_{\text {elevation.age }}<0.001\right)$ and with northward topographical exposure $\left(p_{\text {cos-aspect age }}=0.03\right)$, yet in mid-successional stands larch AGB did not differ discernibly with topography $(p>0.05)$. 


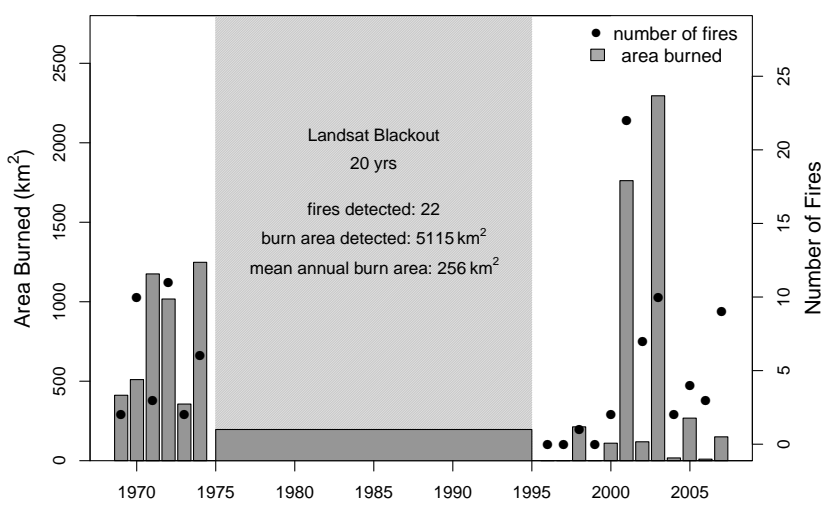

Fig. 6. Estimates of the annual number of fires and area burned across the lower Kolyma River watershed between c. 1969 and 2007. The annual number of fires and area burned varied considerably among years, with 2003 being an exceptionally large fire year across Siberia.

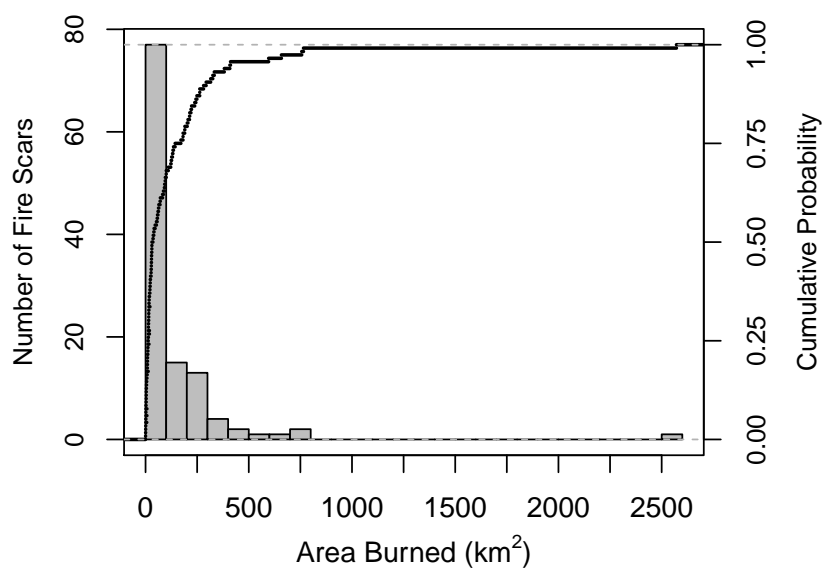

Fig. 7. Frequency and empirical cumulative distribution function plots of fire scar size. Fires were generally quite small, with $75 \%$ smaller than $150 \mathrm{~km}^{2}$ and $5 \%$ greater than $400 \mathrm{~km}^{2}$.

\section{Discussion}

\subsection{Distribution and mapping of larch aboveground biomass}

Understanding the current magnitude and distribution of forest biomass along the forest-tundra ecotone is important given ecosystem feedbacks to climate (Goetz et al., 2007) and necessitates the development of satellite-derived datasets and analytical techniques that can be used to map and detect changes in forest cover over time (Ranson et al., 2011). Cajander larch AGB tended to be low $\left(\sim 1200 \mathrm{~g} \mathrm{~m}^{-2}\right)$ across the forest-tundra ecotone in northeastern Siberia and exceeded $6000 \mathrm{~g} \mathrm{~m}^{-2}$ only under favourable site conditions and in the absence of recent fire. Previous work has shown that in Siberia's northern permafrost zone AGB in larch stands rarely exceeds $10000 \mathrm{~g} \mathrm{~m}^{-2}$, while in southern regions AGB in mature stands often exceeds $15000 \mathrm{~g} \mathrm{~m}^{-2}$ (Kajimoto et al., 2010). Areas of high AGB tended to occur along low elevation mountain valley slopes, though also in fire-protected corridors formed by mountain streams and on elevated ridges in the wet lowland areas.

The spatial distribution of larch AGB was relatively well captured by the two MODIS-derived tree canopy cover products that we examined. Unlike traditional categorical land cover maps, these products provide continuous estimates of tree cover at global (Hansen et al., 2003) and biome-level (Ranson et al., 2011) extents. The broad spatial coverage, moderate spatial resolution, and quantification of tree cover along a continuous gradient makes these products important tools that can be used with in situ measurements and other satellite-derived datasets to better understand multi-decadal changes in vegetation dynamics in the boreal biome (Berner et al., 2011).

Mapping forest biomass in the boreal biome using satellite imagery has met with mixed success (Houghton et al., 2007; Leboeuf et al., 2012), though combining measurements from multiple satellites can help overcome limitations of individual sensors and improve biomass mapping efforts (Goetz et al., 2009). Here we used a multi-sensor approach based on high and medium-resolution optical imagery to help ameliorate the trade-off between spatial resolution and extent. The high resolution imagery made it possible to map a surrogate for AGB (i.e., tree shadows) and capture fine spatial variability in AGB, while incorporating medium resolution imagery allowed us to model AGB across an area approximately 50 times the size imaged by the high resolution sensor. Directly mapping AGB by linking field and satellite measurements made it possible to quantify finer spatial variability in AGB than would have been possible had the analysis relied upon assigning field AGB measurements to thematic land cover types (Goetz et al., 2009; Baccini et al., 2012). By mapping tree shadows from multi-sensor satellite imagery we were able to derive a surrogate for larch AGB and then use this surrogate with field measurements to model the regional forest biomass distribution.

Tree shadows mapped from high-resolution satellite images have exhibited modest to strong relationships with a number of structural attributes in both coniferous and deciduous forests (Greenberg et al., 2005; Leboeuf et al., 2012; Wolter et al., 2012). We found that field measurements of AGB and canopy cover were strongly associated with tree shadow fraction, while tree height and density were not as closely related with shadows. Leboeuf et al. (2012) also observed that tree shadow fraction in the coniferous forests of northeastern Canada was more closely associated with tree volume and basal area than it was with crown closure or tree height. Tree height, diameter, density and distribution are all factors that contribute to AGB in a forest stand, as well as to the shadow cast by that group of trees. As such, it is not surprising that AGB appears more closely related to tree shadow fraction than do other measurements 


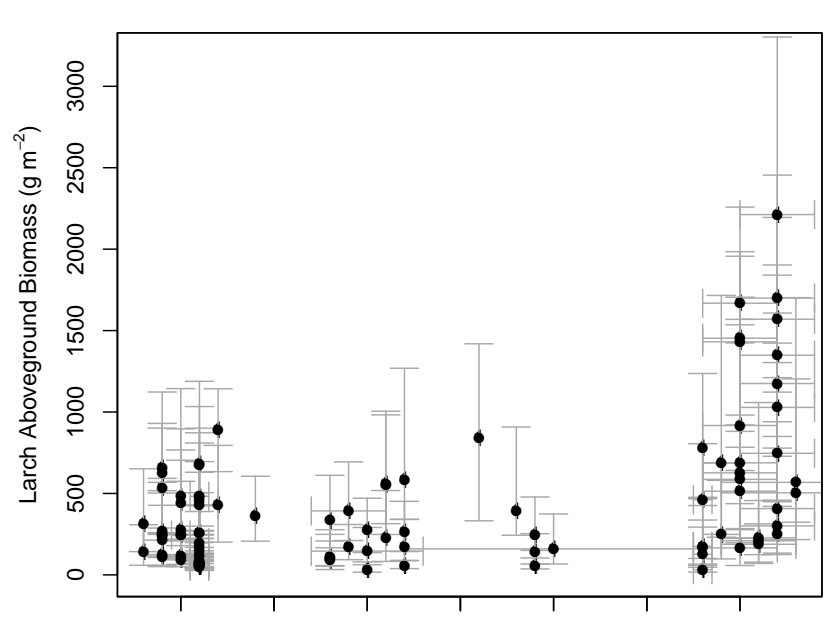

Fig. 8. Cajander larch aboveground biomass (AGB) across 98 fire scars that burned in the lower Kolyma River watershed between c. 1969-2005. Each point represents the median larch AGB in a fire scar, while y-error bars indicate 25th and 75th percentiles in AGB and $\mathrm{x}$-error bars indicate the range of uncertainty in when the fire occurred.

of forest structure. Similarly, light detection and ranging (LiDAR) measurements generally show stronger relationships with stand-level AGB than with tree height (Goetz and Dubayah, 2011). While the correlations among forest attributes and tree shadow fraction mapped from WorldView1 and Landsat 5 were quite similar for AGB, canopy cover and tree height, the difference between sensors was notable in correlation with tree density. Tree density correlated more strongly with tree shadows mapped from WorldView-1 $(r=0.71)$ than with tree shadows mapped from Landsat 5 $(r=0.54)$, yet neither correlation was as strong as that reported by Greenberg et al. (2005) $(r=0.87)$, who compared tree density derived from photo interpretation with tree shadows mapped from IKONOS. We found that in the open larch forests of northeastern Siberia tree shadows were a good proxy for AGB and canopy cover, though did not as closely reflect tree height or density.

Efforts to map attributes of forest structure across broad spatial extents can be improved by first mapping forest structure at a higher spatial resolution and then using the resulting maps to train statistical models to predict the attributes of interest based on coarser resolution multi-spectral satellite data. Tree shadow fraction predicted using the Random Forest model exhibited a stronger relationship with field measurements of larch AGB $(r=0.91)$ than did any of the individual Landsat predictor variables $(|r|=0.04$ to 0.82$)$. The Random Forest model identified the SWIR and red bands as the variables of greatest importance for predicting tree shadow fraction and, incidentally, these variables also exhibited the strongest correlations with field measurements of AGB $(r=-0.77$ to -0.82$)$. The applicability of reflectance data in the SWIR and red bands to mapping forest AGB has previously been demonstrated (Steininger, 2000; Fuchs et al., 2009; Baccini et al., 2012). Reflectance in SWIR decreases with increasing biomass due to shadows generated by heterogeneity in stand structure (Baccini et al., 2012). Similiar to Fuchs et al. (2009), we found that vegetation indices (NDVI and SAVI) showed little to no relationship with tree AGB, potentially due to the decoupling of productivity and standing biomass. Furthermore, vegetation indices are affected by productivity of understory vegetation (shrubs, herbs, mosses and lichens), which were not included in our AGB estimates. Linking high and medium resolution satellite data focused on the red and SWIR wavelengths shows considerable promise for improving biomass mapping efforts and warrants further attention.

Using field and multi-satellite data we estimated larch AGB across approximately $100000 \mathrm{~km}^{2}$; however, we encountered a number of challenges and potential sources of error. We had a limited number of field AGB measurements $(n=25)$ owing to logistical challenges, which is common in studies of Siberian forest biomass (Fuchs et al., 2009; Schulze et al., 2012). Another issue was that fieldwork was conducted in 2010 and 2011, but persistent cloud cover in the region made it necessary to use Landsat 5 and WorldView1 images from 2007 and 2009, respectively (we note the field sites were not disturbed in the intervening years). Coregistration of geospatial datasets was also challenging and necessitated considerable care to ensure proper overlap between datasets. Using tree shadows to map forest AGB might have resulted in underestimating AGB in high density stands because of overlapping shadows. Comparison of the WorldView-1 images with digital photographs taken across the study area revealed that when the WorldView-1 images were acquired snow tended to mask much of the low stature birch and willow shrub cover found in upland forests, while in some riparian areas tall willow and alder protruded above the snow. Though many of these tall riparian shrubs were excluded from the analysis as part of our liberal water mask, in some instances the shadows generated by these shrubs were included in the tree shadow maps. This likely lead to an over estimation of larch AGB in riparian areas. Additional work is needed to understand the contribution of shrubs to carbon pools in this region. Selection of a different threshold value used for mapping tree shadows from the WorldView-1 imagery could have also affected AGB estimates. In spite of these limitations and potential sources of error, we observed strong relationships among tree shadow fraction and field measurements of larch AGB, as well as favourable agreement among our map of larch AGB and independent tree canopy cover estimates. Our map can be used to help understand factors that affect the magnitude and distribution of larch biomass along the forest-tundra ecotone in northeastern Siberia. In addition to demonstrating a multi-sensor technique for regional mapping of AGB that can potentially be applied to other forest ecosystems, our study contributes to a growing body of literature that examines how the structural 
attributes of forests can be mapped from satellite images based on tree shadows.

\subsection{Fire regime along the forest-tundra ecotone in northeastern siberia}

It is important to develop means for quantifying and monitoring fire activity using satellite-based approaches so as to better inform fire management decisions and better characterise the carbon implications of forest recovery from disturbance (Goetz et al., 2012). Although our principal purpose for mapping fires was to quantify post-fire biomass recovery, we also used the mapped fire scars to provide an initial overview of the regional fire regime and to evaluate performance of the MODIS burned area product. Based on analysis of satellite imagery from 1972-2007 and from 20002007, we estimated the fire rotation across the forest-tundra ecotone to be 301 and $397 \mathrm{yr}$, respectively. Subdividing the ecotone into southern mountain larch forests and northern lowland forest-tundra revealed that fire rotation differed sevenfold between these two zones (110 vs. $792 \mathrm{yr}$ ). This spatial pattern of fire activity is similar to that observed across Siberia, with fire return interval generally increasing from south to north (Furyaev et al., 2001; Soja et al., 2004; Kharuk et al., 2011) and correlated with both summer temperatures and AGB (Furyaev et al., 2001). Our ecotone-level estimates of fire rotation are similar to the mean fire return interval calculated for Siberia's northern sparse forests $(227-556 \mathrm{yr}$, mean $=357 \mathrm{yr}$ ) from AVHRR satellite data (Soja et al., 2006). Furthermore, they are similar to dendrochronological estimates of fire return interval along the forest-tundra ecotone in central Siberia $(130-350 \mathrm{yr}$, mean $=200 \pm 50 \mathrm{yr}$ ) (Kharuk et al., 2011). Our fire rotation estimate for the mountain larch forests $\left(64.5-67^{\circ} \mathrm{N}\right)$ was slightly greater than the fire return interval determined for larch-dominated communities $\left(\sim 64^{\circ} \mathrm{N}\right)$ in central Siberia (Kharuk et al., 2008, 2011), potentially due to slightly cooler temperatures and less human disturbance of the landscape.

Mean annual fire density has been estimated to be 2.0 fires per $10^{4} \mathrm{~km}^{2}$ for Siberian mountain-tundra open forests (Valendik, 1996; Furyaev et al., 2001), though in our study area annual fire density between 2000-2007 averaged $0.3 \pm 0.3$ fires per $10^{4} \mathrm{~km}^{2}$ along the forest-tundra ecotone and $1.0 \pm$ 1.0 fires per $10^{4} \mathrm{~km}^{2}$ in the Kolyma Mountains. Across intact tracts of central and southern taiga, average annual fire density, as calculated using MODIS satellite imagery from 2002-2005, was $1.8 \pm 0.8$ fires per $10^{4} \mathrm{~km}^{2}$ (Mollicone et al., 2006). Since annual fire counts in Siberia tend to decrease moving northward (Soja et al., 2004), our results and those of Mollicone et al. (2006) together suggest that the estimated average annual fire density of 2.0 fires per $10^{4} \mathrm{~km}^{2}$ for mountain-tundra open forests is probably too high. Fire density in the Kolyma Mountains exceeded 2.0 fires per $10^{4} \mathrm{~km}^{2}$ only during the abnormally hot summer of 2001, when it peaked at 3.4 fires per $10^{4} \mathrm{~km}^{2}$. Average annual fire den- sity in the Kolyma Mountains was about 1/5 that reported for boreal spruce sites in Interior Alaska for 1992-2001 (DeWilde and Chapin, 2006). These regional differences in fire counts are driven by differences human and lightning ignitions (Conard and Ivanova, 1997; Kovacs et al., 2004; Mollicone et al., 2006), vegetation fuel load and flammability (Furyaev et al., 2001; Sofronov and Volokitina, 2010), and the frequency of hot and dry weather that promotes the outbreak of fire (Balzter et al., 2005; Bartsch et al., 2009; Kharuk et al., 2011).

While fire activity varied across the landscape, we also observed considerable interannual variability, which previous work in Siberia has attributed to human activities (Mollicone et al., 2006) and to the impact of hemispheric climate conditions (e.g., Arctic Oscillation (AO)) (Balzter et al., 2005) on summer temperatures (Kharuk et al., 2011) and fuel moisture (Bartsch et al., 2009). Consistent with weather being an important driver of fire activity (Stocks et al., 1998), we found that fire activity was positively associated with air temperatures during the hottest months of the year (July). In our study area, the two hottest Julys over the 1901-2009 CRU dataset occurred in 2001 and 2003, which coincided with the two largest burn years that we recorded. Eurasia experienced a record-breaking heat wave in 2003 (IPCC, 2007) that was associated with an extreme fire season across Siberia (Soja et al., 2007). Extreme fire events in the larch-dominated forests of central Siberia have previously been linked with summer air temperature deviations (Kharuk et al., 2008). During the positive phase of the $\mathrm{AO}$, high pressures at northern mid-latitudes enhance the drying of phytomass and lead to a positive association between annual burned area and summer temperatures in central Siberia (Balzter et al., 2005). Increased summer air temperatures, as are projected for the coming century (IPCC, 2007), will likely lead to increased fire activity across the region (Stocks et al., 1998).

Obtaining an accurate picture of fire activity across Siberia necessitates the use of satellite data (Soja et al., 2004); however, systematic mapping of fires across broad spatial extents is not a trivial undertaking due to the necessity of using medium to coarse resolution datasets, the presence of thick clouds and smoke, and temporal changes in the optical characteristics of burned areas (Roy et al., 2008). In our study area, MODIS considerably underestimated the total area burned in comparison to that mapped using Landsat, though MODIS did detect the fires that were responsible for the vast majority of the area burned. The underestimation of burned area is likely a result of the MODIS product pixel resolution $(500 \mathrm{~m})$, persistent cloud cover, and the hotspot detection technique for screening false positives (Roy et al., 2005, 2008). We found the MODIS burned area product useful for identifying the year in which a Landsat-mapped fire occurred, though note that in northeastern Siberia it underestimated fire sizes and consequently total area burned.

While our newly created fire scar database allowed us to estimate elements of the fire regime and partially evaluate 
the MODIS burned area product, we encountered a number of difficulties in constructing the database. The principle source of uncertainty stemmed from the $20 \mathrm{yr}$ gap in Landsat data. This gap in imagery hindered our ability to detect and date fires that occurred between 1975-1995, though we were able to approximately date many of the larger fires during this period using the GIMMS NDVI record. We likely underestimated both the total number of fires and area burned during this period, which means that we consequently underestimated the fire density and overestimated fire rotation. Nonetheless, fire rotation across the full record (c. 19662007) was shorter than when calculated only for the period 2000 and 2007. We had expected the fire rotation calculated for the most recent period to be shorter since fire activity has generally been increasing across Siberia since the 1980s and both 2001 and 2003 were extreme fire years (Soja et al., 2007). The $20 \mathrm{yr}$ gap in Landsat imagery likely biased the fire record towards large fires and fires with minimal regrowth, since we were more likely to detect these fires following the resumption of satellite imaging. In spite of these limitations, the fire scar record that we created from Landsat data made it possible for us to not only assess forest regrowth following fire, but also derive best-estimates of fire regime characteristics and evaluate the MODIS burned area product for an area that has not been well studied. Future research on the regional fire regime could include a more exhaustive evaluation of burned area products, as well as investigation of the historical fire frequency using tree ring data.

\subsection{Accumulation of larch aboveground biomass following fire}

While most satellite analyses of forest regrowth after fire have used NDVI as a proxy to assess the recovery of functional attributes (e.g., leaf area or net primary productivity) (Hicke et al., 2003; Goetz et al., 2006; Cuevas-González et al., 2009), we quantified the recovery of a structural attribute during early and mid-succession by mapping larch AGB across 98 fire scars. Our resulting estimates of landscapelevel larch AGB accumulation after fire agreed well with stand-level measurements made by Alexander et al. (2012). Our finding that larch AGB tended to be low and change little during early succession is consistent with the in situ observations of minimal larch recruitment, low larch AGB, and low aboveground net primary productivity (ANPP) at sites younger than $20 \mathrm{yr}$. Our estimate of larch AGB in stands that were $33-38$ yr old $\left(746 \pm 100 \mathrm{~g} \mathrm{~m}^{-2}, n=33\right)$ was also similar to field observations $\left(876 \pm 497 \mathrm{~g} \mathrm{~m}^{-2}, n=3\right.$, Alexander et al., 2012) and supports the notion that larch tend to re-achieve dominance $20-50 \mathrm{yr}$ after fire (Zyryanova et al., 2007, 2010). We found that low elevation, south-facing slopes provided the best site conditions for tree growth and biomass accumulation during early succession, and likely across the full successional cycle. Soils tend to be warmer and thicker on low elevation, south-facing slopes than on high elevation, north-facing slopes (Yanagihara et al., 2000; Noetzli et al., 2007), which increases soil respiration and nitrogen availability (Yanagihara et al., 2000; Matsuura and Hirobe, 2010) and leads to both higher net photosynthetic rates and annual larch shoot growth (Koike et al., 2010). Though larch AGB was highly variable during mid-succession (33$38 \mathrm{yr}$ ), the mixed linear model found no evidence to support that elevation or aspect drove this variability. It is possible that we were not able to detect the effects due to the relatively short time period examined ( $6 \mathrm{yr})$, the limited number of fire scars $(n=32)$, and potential errors in the AGB and elevatioan models. We found no evidence to support the hypothesis that differences in latitude affected larch AGB accumulation rates, potentially due to the relatively limited range in latitudes $\left(\sim 5^{\circ}\right)$ and the modest climatic gradient that this encompassed.

While topographically-dictated site micro-climates affect patterns of forest regrowth after fire, characteristics of the initial fire disturbance (e.g., fire size or severity) can also impact the trajectory of forest regrowth (Zyryanova et al., 2007; Sofronov and Volokitina, 2010). We had predicted that larch AGB accumulation after large fires would occur more slowly than after small fires due to a possible increase in proximity to seed sources, which would lower the density of tree regrowth and thus subsequent AGB accumulation. We found no evidence, however, to support the hypothesis that fire size affected rates of post-fire larch AGB accumulation. To our knowledge, the maximum seed dispersal range for Cajander larch is unknown, though seeds of a related species in North America (Larix laricinia) were found to stay largely within $20 \mathrm{~m}$ of the seed tree (Brown et al., 1988). Though long-distance seed dispersal cannot be ruled out, the lack of association between fire size and subsequent rates of larch AGB accumulation might mean that regrowth is more dependent upon seeds generated by surviving trees within a fire scar than on seeds blown into a fire scar from neighbouring unburned stands. While fires can cause high tree mortality in larch forests (Abaimov et al., 2000; Zyryanova et al., 2007), we observed a six-fold range in AGB in the four years immediately following fire, suggesting a range in post-fire tree survival. Trees that survive a fire often exhibit a period of rapid growth (Furyaev et al., 2001; Sofronov and Volokitina, 2010) and produce seeds that fall upon thinner soil organic layers where they are more likely to successfully germinate and become established (Sofronov and Volokitina, 2010). If longrange seed dispersal is limited and recovery of Cajander larch forests is dependent upon trees that survived a fire, along with remnant unburned patches within the fire scar, then an increase in fire severity might reduce seed availability by reducing tree survival. More work is needed to understand seed dispersal and the role it plays in forest recovery after fire.

Our study quantified post-fire forest recovery and examined the roles of topography and fire size in shaping regrowth trajectories, but there were several sources of uncertainty. Primary among these were potential errors in our AGB model 
and the difficulty of precisely dating fire scars. Though we observed a strong relationship between $\mathrm{TSF}_{\mathrm{LS}}$ and field measurements of AGB $\left(r^{2}=0.91\right)$, the linear model RMSE was $622 \mathrm{~g} \mathrm{~m}^{-2}$, which was in the range of AGB values that we observed across fire scars. This model error could have affected our estimates of both larch AGB and rates of post-fire AGB accumulation, as well as hindered our ability to detect potential effects related to fire size and topography. Additionally, errors in dating fire scars increased with years since fire and could have also affected our estimates of AGB accumulation.

There are a number of unanswered questions related to how fire characteristics and site conditions affect post-fire biomass accumulation. For instance, how does fire severity affect regrowth density and subsequent trajectories of AGB accumulation? What factors govern fire-induced tree mortality and how do surviving trees and proximity to fire perimeter impact spatial variability in forest recovery? How might increases in regional vegetation productivity ("greening"), as have been observed from satellite measurements in recent decades (Beck and Goetz, 2011; Berner et al., 2011), affect fuel loads, fire activity and post-fire regrowth? Furthermore, how do fires affect permafrost and the vast pools of organic carbon stored within these frozen soils (Zimov et al., 2009)? Future research is needed to address these and other questions related to disturbance factors governing the loss and accumulation of carbon in the larch forests of northeastern Siberia.

\section{Conclusions}

Siberian boreal forests are strongly affected by ongoing climatic changes that are likely to result in large feedbacks to the global climate system. Quantifying the net climate feedback in boreal Siberia will necessitate understanding the relationships among climate, fire regimes and vegetation dynamics, yet considerable uncertainty remains in forest $\mathrm{C}$ pools, fire dynamics and post-fire forest recovery across this remote and expansive biome. We found that the AGB of larch forests varied considerably during the first few years after fire, suggesting variability in post-fire tree mortality. Larch AGB accumulation was minimal during early succession $(\leq 25 \mathrm{yr})$ and then increased rapidly during mid-successional (33-38 yr) as larch resumed dominance. Larch regrowth decreased with increased elevation and northwardly aspect, at least during early succession, while neither fire size nor latitude appeared to affect rates of regrowth. Field measurements of forest structure (e.g., AGB, canopy cover), linked with tree shadows synergistically mapped using high and medium resolution satellite imagery, permitted spatial extrapolation of forest structure variables to regional extents with a high degree of accuracy. Similar derivation of datasets and application of analysis techniques are needed for characterising forest biomass distribution, disturbance regime dynamics and the response of ecosystems to disturbance events in order to improve prediction of the net climatic feedbacks associated with landscape scale forest disturbance, particularly in the relatively poorly studied regions of northern Eurasia.

Acknowledgements. This work was supported by grants to SG and MM from the NASA Carbon Cycle and Ecosystems programme (NNX08AG13G), NOAA Global Carbon Programme (NA08OAR4310526), NSF International Polar Year (0732954) and NSF OPP (76347). Thanks to Andrew Bunn and Karen Frey, as well as to the students of the POLARIS project, for larch biomass data. Thanks also to two anonymous reviewers who provided constructive feedback on the previous version of this manuscript.

Edited by: P. Stoy

\section{References}

Abaimov, A. P.: Geographic Distribution and Genetics of Siberian Larch Species, in: Permafrost Ecosystems: Siberian Larch Forests, edited by: Osawa, A., Zyryanova, O. A., Matsuura, Y., Kajimoto, T., and Wein, R. W., Springer, New York, 41-55, 2010.

Abaimov, A. P., Zyryanova, O. A., Prokushkin, S. G., Koike, T., and Matsuura, Y.: Forest Ecosystems of the Cryolithic Zone of Siberia: Regional Features, Mechanisms of Stability and Pyrogenic Changes, Eur. J. Forest Res., 1, 1-10, 2000.

Akaike, H.: A new look at the statistical model identification, IEEE T. Automat. Contr., 19, 716-723, doi:10.1109/TAC.1974.1100705, 1974.

Alexander, H., Mack, M., Goetz, S., Loranty, M., Beck, P., Earl, K., Zimov, S., Davydov, S., and Thompson, C.: Carbon Accumulation Patterns During Post-Fire Succession in Cajander Larch (Larix cajanderi) Forests of Siberia, Ecosystems, 1-18, doi:10.1007/s10021-012-9567-6, 2012.

Baccini, A., Goetz, S. J., Walker, W. S., Laporte, N. T., Sun, M., Sulla-Menashe, D., Hackler, J., Beck, P. S. A., Dubayah, R., Friedl, M. A., Samanta, S., and Houghton, R. A.: Estimated carbon dioxide emissions from tropical deforestation improved by carbon- density maps, Nature, 2, 182-185, doi:10.1038/nclimate1354, 2012.

Balzter, H., Gerard, F. F., George, C. T., Rowland, C. S., Jupp, T. E., McCallum, I., Shvidenko, A., Nilsson, S., Sukhinin, A., Onuchin, A., and Schmullius, C.: Impact of the Arctic Oscillation pattern on interannual forest fire variability in Central Siberia, Geophys. Res. Lett., 32, L14709, doi:10.1029/2005g1022526, 2005.

Bartsch, A., Balzter, H., and George, C.: The influence of regional surface soil moisture anomalies on forest fires in Siberia observed from satellites, Environ. Res. Lett., 4, 045021, doi:10.1088/1748-9326/4/4/045021, 2009.

Beck, P. S. A. and Goetz, S. J.: Satellite observations of high northern latitude vegetation productivity changes between 1982 and 2008: ecological variability and regional differences, Environ. Res. Lett., 6, 045501, doi:10.1088/1748-9326/6/4/045501, 2011.

Berner, L. T., Beck, P. S. A., Bunn, A. G., Lloyd, A. H., and Goetz, S. J.: High-latitude tree growth and satellite vegetation indices: Correlations and trends in Russia and Canada (1982-2008), J. Geophys. Res., 116, G01015, doi:10.1029/2010jg001475, 2011. 
Bonan, G. B.: Forests and climate change: forcings, feedbacks, and the climate benefits of forests, Science, 320, 1444-1449, doi:10.1126/science.1155121, 2008 .

Breiman, L.: Random Forests, Mach. Learn., 45, 5-32, 2001.

Brown, K. R., Zobel, D. B., and Zasada, J. C.: Seed Dispersal, Seedling Emergence, and Early Survival of Larix Laricina (DuRoi) Koch K. in the Tanana Valley, Alaska, Can. J. Forest Res., 18, 306-314, 1988.

Conard, S. G. and Ivanova, G. A.: Wildfire in Russian Boreal Forests-Potential Impacts of Fire Regime Characteristics on Emissions and Global Carbon Balance Estimates, Environ. Pollut., 98, 305-313, doi:10.1016/s0269-7491(97)00140-1, 1997.

Corradi, C., Kolle, O., Walter, K., Zimov, S. A., and Schulze, E. D.: Carbon dioxide and methane exchange of a north-east Siberian tussock tundra, Glob. Change Biol., 11, 1910-1925, doi:10.1111/j.1365-2486.2005.01023.x, 2005.

Cuevas-González, M., Gerard, F., Balzter, H., and RiañO, D.: Analysing forest recovery after wildfire disturbance in boreal Siberia using remotely sensed vegetation indices, Glob. Change Biol., 15, 561-577, doi:10.1111/j.1365-2486.2008.01784.x, 2009.

DeWilde, L. O. and Chapin, F.: Human Impacts on the Fire Regime of Interior Alaska: Interactions among Fuels, Ignition Sources, and Fire Suppression, Ecosystems, 9, 1342-1353, doi:10.1007/s10021-006-0095-0, 2006.

Fuchs, H., Magdon, P., Kleinn, C., and Flessa, H.: Estimating aboveground carbon in a catchment of the Siberian forest tundra: Combining satellite imagery and field inventory, Remote Sens. Environ., 113, 518-531, doi:10.1016/j.rse.2008.07.017, 2009.

Furyaev, V. V., Vaganov, E. A., Tchebakova, N. M., and Valendik, E. N.: Effects of Fire and Climate on Successions and Structural Changes in the Siberian Boreal Forest, Eur. J. Forest Res., 2, 115, 2001.

George, C., Rowland, C., Gerard, F., and Balzter, H.: Retrospective mapping of burnt areas in Central Siberia using a modification of the normalised difference water index, Remote Sens. Environ., 104, 346-359, doi:10.1016/j.rse.2006.05.015, 2006.

Goetz, S. and Dubayah, R.: Advances in remote sensing technology and implications for measuring and monitoring forest carbon stocks and change, Carbon Management, 2, 231-244, doi:10.4155/cmt.11.18, 2011.

Goetz, S. J., Mack, M. C., Gurney, K. R., Randerson, J. T., and Houghton, R. A.: Ecosystem responses to recent climate change and fire disturbance at northern high latitudes: observations and model results contrasting northern Eurasia and North America, Environ. Res. Lett., 2, 045031, doi:10.1088/17489326/2/4/045031, 2007.

Goetz, S. J., Baccini, A., Laporte, N. T., Johns, T., Walker, W., Kellndorfer, J., Houghton, R. A., and Sun, M.: Mapping and monitoring carbon stocks with satellite observations: a comparison of methods, Carbon Balance Manag., 4, doi:10.1186/1750-0680-42, 2009.

Goetz, S. J., Bond-Lamberty, B., Law, B. E., Hicke, J. A., Huang, C., Houghton, R. A., McNulty, S., O’Halloran, T., Harmon, M., Meddens, A. J. H., Pfeifer, E. M., Mildrexler, D., and Kasischke, E. S.: Observations and assessment of forest carbon dynamics following disturbance in North America, J. Geophys. Res., 117, G02022, doi:10.1029/2011jg001733, 2012.
Goodale, C. L., Apps, M. J., Birdsey, R. A., Field, C. B., Heath, L. S., Houghton, R. A., Jenkins, J. C., Kohlmaier, G. H., Kurz, W., Liu, S., Nabuurs, G.-J., Nilsson, S., and Shvidenko, A. Z.: Forest carbon sinks in the Northern Hemisphere, Ecol. Appl., 12, 891-899, doi:10.1890/10510761(2002)012[0891:fcsitn]2.0.co;2, 2002.

Greenberg, J. A., Dobrowski, S. Z., and Ustin, S. L.: Shadow allometry: Estimating tree structural parameters using hyperspatial image analysis, Remote Sens. Environ., 97, 15-25, doi:10.1016/j.rse.2005.02.015, 2005.

Groisman, P. and Soja, A. J.: Ongoing climatic change in Northern Eurasia: justification for expedient research, Environ. Res. Lett., 4, 045002, doi:10.1088/1748-9326/4/4/045002, 2009.

Groisman, P. Y., Sherstyukov, B. G., Razuvaev, V. N., Knight, R. W., Enloe, J. G., Stroumentova, N. S., Whitfield, P. H., Førland, E., Hannsen-Bauer, I., Tuomenvirta, H., Aleksandersson, H., Mescherskaya, A. V., and Karl, T. R.: Potential forest fire danger over Northern Eurasia: Changes during the 20th century, Global Planet. Change, 56, 371-386, doi:10.1016/j.gloplacha.2006.07.029, 2007.

Hansen, M. C., DeFries, R. S., Townshend, J. R. G., Carroll, M., Dimiceli, C., and Sohlberg, R. A.: Global Percent Tree Cover at a Spatial Resolution of $500 \mathrm{Me}-$ ters: First Results of the MODIS Vegetation Continuous Fields Algorithm, Earth Interact., 7, 1-15, doi:10.1175/10873562(2003)007;0001:GPTCAA ¿2.0.CO;2, 2003.

Hayes, D. J., McGuire, A. D., Kicklighter, D. W., Gurney, K. R., Burnside, T. J., and Melillo, J. M.: Is the northern high-latitude land-based $\mathrm{CO}_{2}$ sink weakening?, Global Biogeochem. Cy., 25, GB3018, doi:10.1029/2010gb003813, 2011.

Heinselman, M. L.: Fire in the virgin forests of the Boundary Waters Canoe Area, Minnesota, Quaternary Res., 3, 329-382, doi:10.1016/0033-5894(73)90003-3, 1973.

Hicke, J. A., Asner, G. P., Kasischke, E. S., French, N. H. F., Randerson, J. T., James Collatz, G., Stocks, B. J., Tucker, C. J., Los, S. O., and Field, C. B.: Postfire response of North American boreal forest net primary productivity analyzed with satellite observations, Glob. Change Biol., 9, 1145-1157, doi:10.1046/j.13652486.2003.00658.x, 2003.

Houghton, R. A., Butman, D., Bunn, A. G., Krankina, O. N., Schlesinger, P., and Stone, T. A.: Mapping Russian forest biomass with data from satellites and forest inventories, Environ. Res. Lett., 2, 045032, doi:10.1088/1748-9326/2/4/045032, 2007.

IPCC: Climate Change 2007: The Physical Science Basis. Contribution of Working Group I to the Fourth Assessment Report of the Intergovernmental Panel on Climate Change, Cambridge, 747845, 2007.

James, T. M.: Temperature sensitivity and recruitment dynamics of Siberian larch (Larix sibirica) and Siberian spruce (Picea obovata) in northern Mongolia's boreal forest, Forest Ecol. Manag., 262, 629-636, doi:10.1016/j.foreco.2011.04.031, 2011.

Kajimoto, T., Osawa, A., Usoltev, V. A., and Abaimov, A. P.: Biomass and Productivity of Siberian Larch Forest Ecosystems, in: Permafrost Ecosystems: Siberian Larch Forests, edited by: Osawa, A., Zyryanova, O. A., Matsuura, Y., Kajimoto, T., and Wein, R. W., Springer, New York, 99-122, 2010.

Kharuk, V. I., Ranson, K. J., and Dvinskaya, M. L.: Wildfires dynamic in the larch dominance zone, Geophys. Res. Lett., 35, L01402, doi:10.1029/2007g1032291, 2008. 
Kharuk, V. I., Ranson, K. J., Dvinskaya, M. L., and Im, S. T.: Wildfires in northern Siberian larch dominated communities, Environ. Res. Lett., 6, 045208, doi:10.1088/1748-9326/6/4/045208, 2011. Koike, T., Mori, S., Zyryanova, O. A., Kajimoto, T., Matsuura, Y., and Abaimov, A. P.: Photosynthetic Characteristics of Trees and Shrubs Growing on the North- and South-Facing Slopes in Central Siberia, in: Permafrost Ecosystems: Siberian Larch Forests, edited by: Osawa, A., Zyryanova, O. A., Matsuura, Y., Kajimoto, T., and Wein, R. W., Springer, New York, 273-287, 2010.

Kovacs, K., Ranson, K. J., Sun, G., and Kharuk, V. I.: The Relationship of the Terra MODIS Fire Product and Anthropogenic Features in the Central Siberian Landscape, Earth Interact., 8, 1-25, doi:10.1175/1087-3562(2004)8;1:TROTTM $\dot{i} 2.0 . C O ; 2,2004$.

Krestov, P. V.: Forest Vegetation of Easternmost Russia (Russian Far East), in: Forest Vegetation of Northeast Asia, edited by: Kolbek, J., Srutek, M., and Box, E., 28, Kluwer, Dordrecht, 93-180, 2003.

Leboeuf, A., Beaudoin, A., Fournier, R., Guindon, L., Luther, J., and Lambert, M.: A shadow fraction method for mapping biomass of northern boreal black spruce forests using QuickBird imagery, Remote Sens. Environ., 110, 488-500, doi:10.1016/j.rse.2006.05.025, 2007.

Leboeuf, A., Fournier, R. A., Luther, J. E., Beaudoin, A., and Guindon, L.: Forest attribute estimation of northeastern Canadian forests using QuickBird imagery and a shadow fraction method, Forest Ecol. Manag., 266, 66-74, doi:10.1016/j.foreco.2011.11.008, 2012.

Liaw, A. and Wiener, M.: Classification and Regression by randomForest, R. News, 2, 18-22, 2002.

Lloyd, A. H., Bunn, A. G., and Berner, L.: A latitudinal gradient in tree growth response to climate warming in the Siberian taiga, Glob. Change Biol., 17, 1935-1945, doi:10.1111/j.13652486.2010.02360.x, 2011.

Loboda, T. V. and Csiszar, I. A.: Reconstruction of fire spread within wildland fire events in Northern Eurasia from the MODIS active fire product, Global Planet. Change, 56, 258-273, doi:10.1016/j.gloplacha.2006.07.015, 2007.

Matsuura, Y. and Hirobe, M.: Soil Carbon and Nitrogen, and Characteristics of Soil Active Layer in Siberian Permafrost Region, in: Permafrost Ecosystems: Siberian Larch Forests, edited by: Osawa, A., Zyryanova, O. A., Matsuura, Y., Kajimoto, T., and Wein, R. W., Springer, New York, 149-163, 2010.

Meyer, D., Tachikawa, T., Kaku, M., Iwasaki, A., Gesch, D., Oimoen, M., Zheng, Z., Danielson, J., Krieger, T., Curtis, W., Haase, J., Abrams, M., Crippen, R., and Carabaja, C.: ASTER Global Digital Elevation Model Version 2 - Summary of Validation Results, Japan-US ASTER Science Team, 1-26, 2011.

Mollicone, D., Eva, H. D., and Achard, F.: Human role in Russian wild fires, Nature, 440, 436-437, doi:10.1038/440436a, 2006.

Noetzli, J., Gruber, S., Kohl, T., Salzmann, N., and Haeberli, W.: Three-dimensional distribution and evolution of permafrost temperatures in idealized high-mountain topography, J. Geophys. Res., 112, F02S13, doi:10.1029/2006jf000545, 2007.

Petrovsky, V. V. and Koroleva, T. M.: On the flora Kolyma River Delta, Bot. J. Linn. Soc., 64, 19-39, 1979.

R Development Core Team: R: A Language and Environment for Statistical Computing, R Foundation for Statistical Computing, Vienna, 2011.
Ranson, K. J., Montesano, P. M., and Nelson, R.: Objectbased mapping of the circumpolar taiga-tundra ecotone with MODIS tree cover, Remote Sens. Environ., 115, 3670-3680, doi:10.1016/j.rse.2011.09.006, 2011.

Roy, D. P., Jin, Y., Lewis, P. E., and Justice, C. O.: Prototyping a global algorithm for systematic fire-affected area mapping using MODIS time series data, Remote Sens. Environ., 97, 137-162, doi:10.1016/j.rse.2005.04.007, 2005.

Roy, D. P., Boschetti, L., Justice, C. O., and Ju, J.: The collection 5 MODIS burned area product - Global evaluation by comparison with the MODIS active fire product, Remote Sens. Environ., 112, 3690-3707, doi:10.1016/j.rse.2008.05.013, 2008.

Schulze, E.-D., Wirth, C., Mollicone, D., von Lüpke, N., Ziegler, W., Achard, F., Mund, M., Prokushkin, A., and Scherbina, S.: Factors promoting larch dominance in central Siberia: fire versus growth performance and implications for carbon dynamics at the boundary of evergreen and deciduous conifers, Biogeosciences, 9, 1405-1421, doi:10.5194/bg-9-1405-2012, 2012.

Sofronov, M. A. and Volokitina, A. V.: Wildfire Ecology in Continuous Permafrost Zone, in: Permafrost Ecosystems: Siberian Larch Forests, edited by: Osawa, A., Zyryanova, O. A., Matsuura, Y., Kajimoto, T., and Wein, R. W., Springer, New York, 59-83, 2010.

Soja, A. J., Sukhinin, A. I., Cahoon, D. R., Shugart, H. H., and Stackhouse, P. W.: AVHRR-derived fire frequency, distribution and area burned in Siberia, Int. J. Remote Sens., 25, 1939-1960, doi:10.1080/01431160310001609725, 2004.

Soja, A., Shugart, H., Sukhinin, A., Conard, S., and Stackhouse, P.: Satellite-Derived Mean Fire Return Intervals as Indicators of Change in Siberia (1995-2002), Mitig. Adapt. Strat. Glob. Change, 11, 75-96, doi:10.1007/s11027-006-1009-3, 2006.

Soja, A. J., Tchebakova, N. M., French, N. H. F., Flannigan, M. D., Shugart, H. H., Stocks, B. J., Sukhinin, A. I., Parfenova, E. I., Chapin, F. S., and Stackhouse, P. W.: Climate-induced boreal forest change: Predictions versus current observations, Global Planet Change, 56, 274-296, doi:10.1016/j.gloplacha.2006.07.028, 2007.

Steininger, M. K.: Satellite estimation of tropical secondary forest above-ground biomass: data from Brazil and Bolivia, Int. J. Remote Sens., 21, 1139-1157, 2000.

Stocks, B. J., Fosberg, M. A., Lynham, T. J., Mearns, L., Wotton, B. M., Yang, Q., Jin, J.-Z., Lawrence, K., Hartley, G. R., Mason, J. A., and McKenney, D. W.: Climate change and forest fire potential in Russia and Canada boreal forests, Climatic Change, 38, 1-13, 1998.

Sukhinin, A. I., French, N. H. F., Kasischke, E. S., Hewson, J. H., Soja, A. J., Csiszar, I. A., Hyer, E. J., Loboda, T., Conrad, S. G., Romasko, V. I., Pavlichenko, E. A., Miskiv, S. I., and Slinkina, O. A.: AVHRR-based mapping of fires in Russia: New products for fire management and carbon cycle studies, Remote Sens. Environ., 93, 546-564, doi:10.1016/j.rse.2004.08.011, 2004.

Tucker, C., Pinzon, J., Brown, M., Slayback, D., Pak, E., Mahoney, R., Vermote, E., and El Saleous, N.: An extended AVHRR 8-km NDVI dataset compatible with MODIS and SPOT vegetation NDVI data, Int. J. Remote Sens., 26, 4485-4498, doi:10.1080/01431160500168686, 2005.

Valendik, E. N.: Ecological aspects of forest fires in Siberia, Siberian J. Ecol., 1, 1-8, 1996.

Venables, W. N. and Ripley, B. D.: Modern Applied Statistics with S, 4 Edn., Springer, New York, 139-178, 2002. 
Wolter, P. T., Berkley, E. A., Peckham, S. D., Singh, A., and Townsend, P. A.: Exploiting tree shadows on snow for estimating forest basal area using Landsat data, Remote Sens. Environ., 121, 69-79, doi:10.1016/j.rse.2012.01.008, 2012.

Yanagihara, Y., Koike, T., Matsuura, Y., Mori, S., Shibata, H., Satoh, F., Masuyagina, O. V., Zyryanova, O. A., Prokushkin, A. S., Prokushkin, S. G., and Abaimov, A. P.: Soil Respiration Rate on the Contrasting North- and South-Facing Slopes of a Larch Forest in Central Siberia, Eur. J. Forest Res., 1, 19-29, 2000.

Zimov, N. S., Zimov, S. A., Zimova, A. E., Zimova, G. M., Chuprynin, V. I., and Chapin, F. S.: Carbon storage in permafrost and soils of the mammoth tundra-steppe biome: Role in the global carbon budget, Geophys. Res. Lett., 36, L02502, doi:10.1029/2008g1036332, 2009.

Zyryanova, O. A., Yaborov, V. T., Tchikhacheva, T. I., Koike, T., Makoto, K., Matsuura, Y., Satoh, F., and Zyryanov, V. I.: The Structural and Biodiversity after Fire Disturbance in Larix gmelinii (Rupr.) Rupr. Forests, Northeast. Asia Eur. J. Forest Res., 10, 19-29, 2007.

Zyryanova, O. A., Abaimov, A. P., Bugaenko, T. N., and Bugaenko, N. N.: Recovery of Forest Vegetation After Fire Disturbance, in: Permafrost Ecosystems: Siberian Larch Forests, edited by: Osawa, A., Zyryanova, O. A., Matsuura, Y., Kajimoto, T., and Wein, R. W., Springer, New York, 83-96, 2010. 